
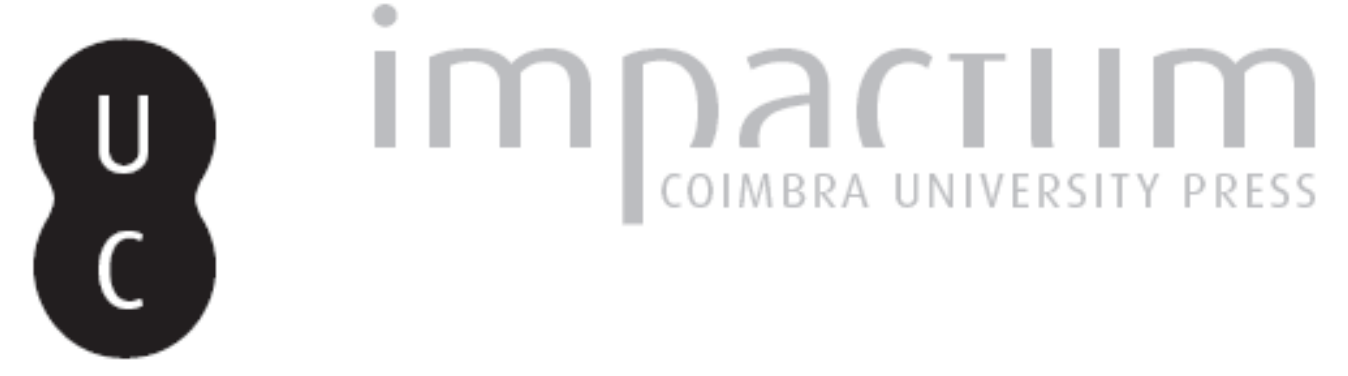

\title{
A Recepção dos Moralia na Pedagogia Renacentista e a Filosofia Estóica de Plutarco na Collectanea Moralis Philosophiae de Frei Luís de Granada
}

Autor(es): $\quad$ Martins, Ana Isabel Correia

Publicado por: International Plutarch Society

URL persistente:

URI:http://hdl.handle.net/10316.2/36351

DOI:

DOI:http://dx.doi.org/10.14195/0258-655X_10_3

Accessed : $\quad$ 26-Apr-2023 11:47:04

A navegação consulta e descarregamento dos títulos inseridos nas Bibliotecas Digitais UC Digitalis, UC Pombalina e UC Impactum, pressupõem a aceitação plena e sem reservas dos Termos e Condições de Uso destas Bibliotecas Digitais, disponíveis em https://digitalis.uc.pt/pt-pt/termos.

Conforme exposto nos referidos Termos e Condições de Uso, o descarregamento de títulos de acesso restrito requer uma licença válida de autorização devendo o utilizador aceder ao(s) documento(s) a partir de um endereço de IP da instituição detentora da supramencionada licença.

Ao utilizador é apenas permitido o descarregamento para uso pessoal, pelo que o emprego do(s) título(s) descarregado(s) para outro fim, designadamente comercial, carece de autorização do respetivo autor ou editor da obra.

Na medida em que todas as obras da UC Digitalis se encontram protegidas pelo Código do Direito de Autor e Direitos Conexos e demais legislação aplicável, toda a cópia, parcial ou total, deste documento, nos casos em que é legalmente admitida, deverá conter ou fazer-se acompanhar por este aviso.

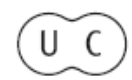




\section{Ploutarchos, n.s.}

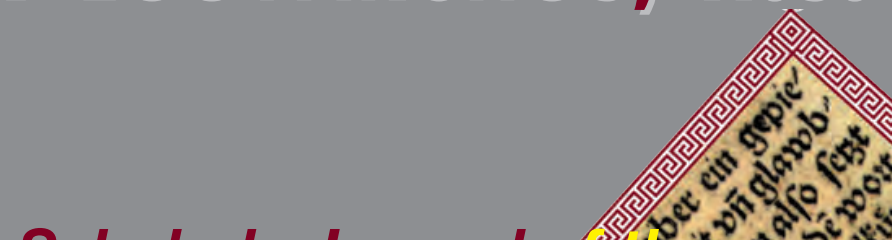

Scholarly Journal or (5) $x, 30$

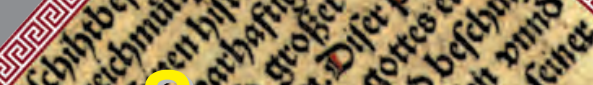

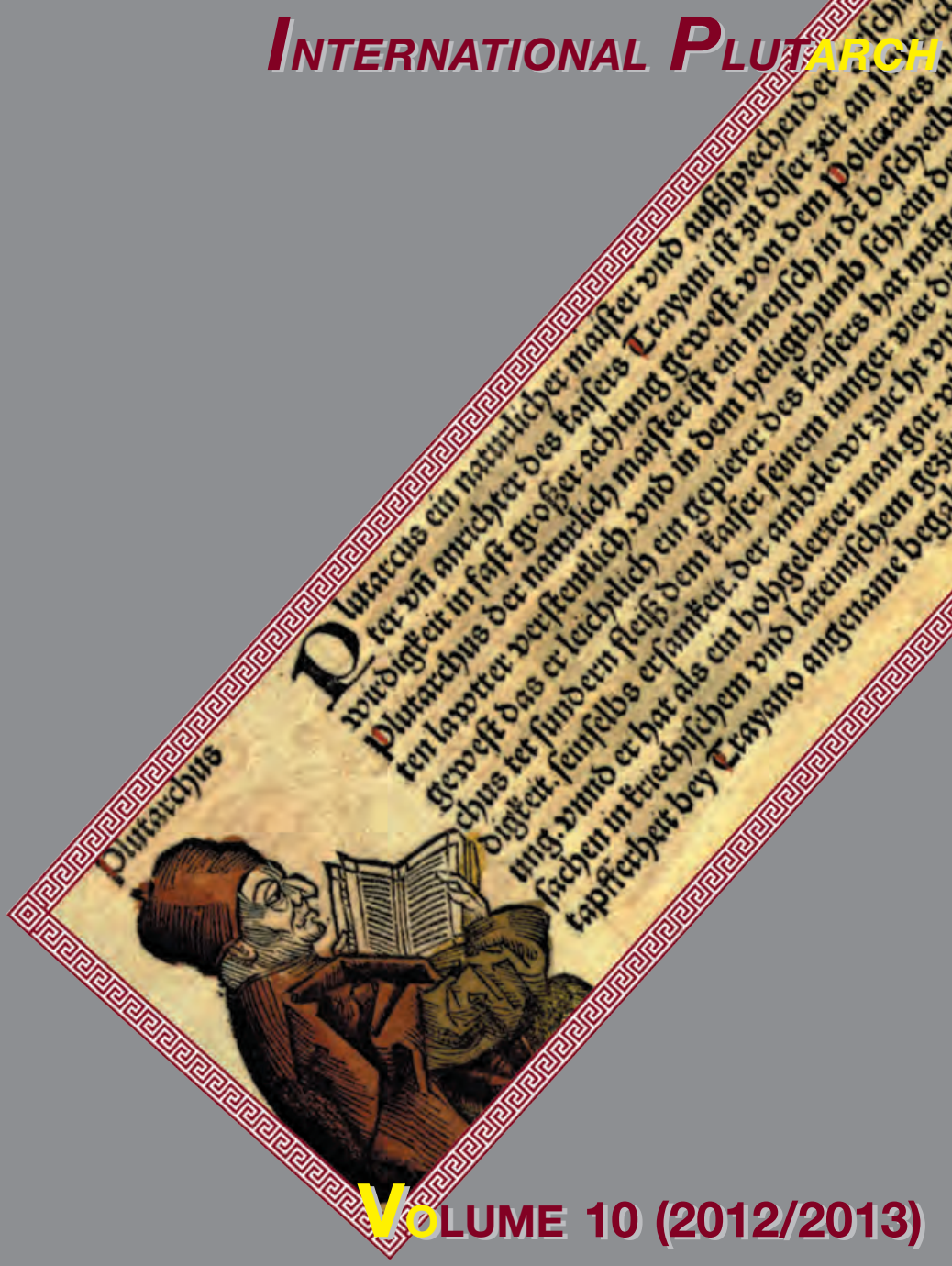

University of Málaga (Spain) Utah State University, Logan, Utah (U.S.A.) 


\title{
A Recepção dos Moralia na Pedagogia Renascentista e a Filo- sofia Estóica de Plutarco na Collectanea Moralis Philosophiae de Frei Luís de Granada \\ por \\ Ana Isabel Correia Martins \\ Universidade de Coimbra \\ anitaamicitia@hotmail.com
}

Literature of this kind has a poeta doctus as its author and requires a litteratus doctus as its recipient.

Heinrich Plett

\begin{abstract}
The European Humanism of Renaissance elected multiplex imitatio as philological method in its encyclopedic productions, based on aemulatio of exempla auctorum, through the assimilation of their precepts and graeco-latins fundamenta. The epistemic and ideological framework of Classical Antiquity, converted in a uox universalis, has promoted the ars combinatoria of humanist writings. The Queronean author was one of the most spread and assimilated authors in this period what is justified by his perennial legacy at the service of moral pedagogy. The Plutarch's ideal of education, as a source of virtue, is a driving force to literary genesis and creation, deeply rooted in the trends of the Renaissance.

In this way, Fray Louis of Grenade was engaged in a proto-mechanism of intertextuality by the revitalization and revalidation of Plutarch's matrixes. The Dominican collected several apophthegmata, from Moralia, in II tomus of his Collectanea Moralis Philosophiae, which is divided in two parts: prima classis in qua ponuntur tituli ad diuersa genera statuum et personarum spectantes; secunda classis, quae communia virtutum et vitiorum loca complectitur. The genus sententiarum, flourished in order to satisfy pedagogical and philological intents and also for the moral education of ethos. The Dominican invokes Virgil's image - the exemplum of the bees that gather pollen - as an argument to defend the methodology: to separate and classify all that was accumulated, from the most important and relevant lessons and then (re) organize and distribute it in common places. This process of variatio ac renouatio converts the collector into auctor.

So, this present article sheds light on the structure of Collectanea, regards the reception of Moralia, justifies the presence and the role of Plutarch, analyses the dialectic nature of topoi, under the scrutiny of (Neo)stoic philosophy.
\end{abstract}

Key-Words: Reception of Moralia, Collectanea Moralis Philosophiae, Neostoicism, Ars colligendi, Genus sententiarum. 


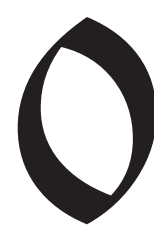

Os principais conceitos filológicos do Humanismo Renascentista

Ajuizar sobre a recepção dos Moralia no Renascimento implica reconhecer, desde logo, a tenacidade dos intelectuais e estudiosos deste período, que envidaram esforços na (re)construção e (re)compilação de um corpus retóricofilosófico, empresa que começa com a descoberta dos manuscritos, passando pelas suas traduções e respectivos comentários. Na verdade, o Humanismo Europeu elegeu a multiplex imitatio como preferencial método filológico das suas produções enciclopédicas e é, por isso, subsidiário da aemulatio dos exempla auctorum, da assimilação dos preceitos e fundamenta greco-latinos. A matriz epistémica e ideológica da Antiguidade Clássica, convertida em uox universalis, é reincorporada nas produções quinhentistas pela mestria da ars combinatoria dos seus autores.

Durante o Renascimento empreende-se um movimento cultural que se detem em todos os campos de activi- dade intelectual, com um denominador comum, pelo qual se afina toda a produção filosófica-literária: a confiança no Homem enquanto emanação divina. Por esta razão, a concretização retórica e cívica das suas principais dimensões - homo sapiens et homo politicus $^{1}$ - imperam na esteira da máxima terenciana: homo sum: humani nihil a me alienum puto $^{2}$.

O dominicano Frei Luís de Granada (1504-1588) deu o seu contributo neste exercício de reescrita, recolhendo o legado perene de muitos autores e em particular de Plutarco, que colocou ao serviço da Pedagogia Moral, da Génese e Criação Literárias. Plutarco, designado o "breviário do século", tornou-se um dos mais difundidos e assimilados autores neste perído, defendendo o ideal de educação como a principal fonte de virtude, passível esta ser ensinada, à luz da conhecida metáfora do campo ${ }^{4}$. O nosso Dominicano vai rentabilizar esta analogia na sua Collectanea Moralis Philosophiae para argumentar que o complexo processo de aprendizagem depende de três variáveis pedagógicas: a natureza predisposta do discípulo à imagem da fertilidade dos

1 Nair de Nazaré Castro Soares et alii, Homo eloquens et homo politicus. A retórica e a construção da cidade da Idade Média e no Renascimento, Centro de Estudos Clássicos e Humanísticos, Coimbra, 2009, p.83

2 Terêncio (195-159 a. C), Heauton Timorumenos, Lugd. Batavorum, apud Franciscum Hackium, 1651.

3 R. Aulotte, Amyot et Plutarque, la tradition des Moralia au XVI. Droz, Genènve, 1965, p.19.

4 Dominique Faure, L'éducation selon Plutarque d'après les Oeuvres Morales, 2 vols, Aix-enProvence, 1960; José Ribeiro FerreirA, «Os valores de Plutarco e sua actualidade», in Ética e Paideia em Plutarco, Colecção Autores Gregos e Latinos, Série ensaios, nº 1, Coimbra, 2008. 
campos, os preceitos teóricos consistentes como sementes que virão a florescer e a dedicação do mestre semelhante ao empenho do agricultor.

Frei Luís de Granada empenhou-se, assim, na construção da Colectânea segundo um proto-mecanismo de intertextualidade, movendo-se na interface da História, Retórica e Pedagogia ${ }^{5}$. A História, informadora de exempla, inspirou a inuentio humanista, moldou novos horizontes ideológicos e desempenhou um papel referencial na instituição de direitos e deveres, onde a moral e a dignitas hominis $^{6}$ têm primazia assim reitera P.O.Kristeller «the emphasis on moral virtue as the self contained end on human life, in the first place, a standard of individual conduct» ${ }^{7}$.

A Retórica, enquanto mater disciplinarum, está intrinsecamente ligada a um programa pedagógico, desde a apreensão das técnicas discursivas até aos exercícios mais complexos de composição literária. Peter Mack na sua obra
The History of Renaissance Rhetoric apresenta um estudo sobre a História e a Pedagogia Retórica estruturado sob os seguintes pontos: i) as consequências da valorização do conhecimento da literatura Clássica e do seu mundo epistémico, ii) o lugar da Retórica na Educação, iii) a relação da Dialéctica com a Retórica, iv) a imitatio destes princípios clássicos no conceito de inovação e renouatio renascentistas ${ }^{8}$. De facto, uma das questões matriciais no estudo da Retórica prende-se com os conceitos de Copia e Imitatio, cata-lisadores dos programas educativos fomentados por toda a Europa e nos quais o papel das sententiae, provérbios, apophthegmata é preponderante 9 .

A partir da época helenística, as colectâneas de sentenças conhecem expressiva divulgação, convertem-se em instrumentos pedagógicos nas escolas de Retórica e Filosofia: «elles ecartent du modus oratorius la tentation sofistique, elles font du discours l'enchâssement de "choses" à la fois

5 Antoine Compagnon, La seconde main ou le travail de citation, Éditions du Seuil, Paris, 1979.

6 A dignitas hominis foi um topos recorrente e de eleição entre os humanistas, vide a este propósito Nair de Nazaré Castro Soares «A Historiografia do Renascimento em Portugal: Referentes estéticos e ideológicos Humanistas» in Aquém e Além da Taprobana, Estudos Luso-Orientais à memória de Jean Aubin e Denys Lombard, Centro de História e de Além-Mar, Lisboa, 2002; _, "Humanismo e História: ars scribendi e valor do paradigma", Universidade Católica Portuguesa”, Sep. De Máthesis 1, 1992.

7 P.O Kristeller, Studies in Renaissance Thought and Letters, Edizioni DI Storia E Letteratura, Roma, 1969, p.136.

8 Peter Mack, A History of Renaissance Rhetoric 1380-1620, Oxford University Press Inc., New York, 2011.

9 Terence Cave, Cornucopia - Figures de l'abondance au XVI siècle : Erasme, Rabelais, Ronsard, Montaigne, Macula Collection Argo, Paris, 1997. 
solides et plaissantes, alliant de docere au delectare $"{ }^{10}$. O nosso Dominicano invoca também, o exemplum da abelha sugerida por Virgílio para justificar e validar a sua metodologia: separar e classificar tudo o que foi acumulado a partir das mais diversas lições, (re) organizar e distribuir por lugares comuns -loci communes ${ }^{11}$. Neste processo de variatio ac renouatio humanistas converte-se o collector historiográfico em auctor literário e reconhecendo-se o mérito, o enciclopedismo e o sentido crítico dos seus agentes ${ }^{12}$.

Neste sentido, o presente estudo visa reflectir sobre os seguintes pontos: 1) Quais são os moldes em que se opera a recepção de Plutarco na Collectanea Moralis Philosophiae? Isto é, quais são os tratados morais que satisfazem os intuitos da obra? 2) Quais são os níveis de recepção intertextual - lembrando que esta obra latina levanta a questão quanto à tradução para Latim da produção do autor de Queroneia; 3) Como se harmoniza a Filosofia de Plutarco com a Teologia do Dominicano? Que orientação é dada na leitura dos autores da Antiguidade pagã, subordinando-os à mensagem da doutrina cristã?

1. A recepção de Plutarco na Collectanea Moralis Philosophiae de Frei Luís de Granada: a carta introdutória ao pio e benévolo leitor

Interpretar a presença de Plutarco na Collectanea Moralis Philosophiae exige concentrar, preliminarmente, a nossa atenção na carta introdutória, dirigida ao pio e benévolo leitor - pio ac bevevolo lectori. Nestas palavras iniciais, escritas em latim, o autor confessa os seus propósitos literários, expõe as suas preferências pessoais, justifica escolhas metodológicas e revela inclusivamente algumas chaves de leitura. Ainda assim, estas páginas iniciais são sempre insuficientes, não bastam para alcançar todas as leituras que a Collectanea sugere nem para orientar todas as interpretações e análise hermenêuticas. Nessa dialéctica Revelação/Enigma, o leitor reconhece, desde logo, que a prin-

10 M. Fumaroli, L'âge de l'Éloquence Rhetorique et «res literaria» de la Renaissance au seuil de l'époque classique, Librairie Droz, Genève, 2002, p.96

«Apes, ut aiunt, debemus imitari, quae vagantur et flores ad mel faciendum idóneos carpunt. Deinde quidquid attulere disponunt ac per favos diferunt et (ut Vergilius noster ait) liquentia mela stipant et dulci distendum nectare cellas. Nos quoque has apes debemus imitari et quaecunque ex diversa lectione congessimus separare melius enim distincta servantur» in Carta introdutória da Collectanea Moralis Philosophiae.

12

José Aragues Aldaz, «Colecciones de exempla y oratória: la labor del compilador» in Humanismo e Pervivencia del Mundo Clásico - Actas del I Simposio, Cádiz, 1993, pp251-267; Nair de NAzaré Castro Soares, «A literatura de sentenças no Humanismo Português: res et uerba», Humanitas 43-44 (Coimbra, 1991-1992) - Actas do Congresso Internacional "Humanismo Português na época dos Descobrimentos" (Coimbra, 9-12 de Outubro de 1991), Coimbra, 1993, p. 377 - 410 
cipal preocupação do Dominicano é a dignitas hominis e a sua concretização em todas as dimensões humanas, seja na representação das suas relações com a sociedade -homo politicus ac homo eloquens - seja na relação consigo mesmo enquanto - homo sapiens et beatus, na reinvidicação assídua e constante da verdade e da justiça ${ }^{13}$. Os humanistas enfrentam o problema da verdade nas suas discussões filosóficas e nas suas produções literárias, especialmente nos problemas morais que são considerados os domínios mais legítimos do Homem.

O Dominicano sempre revelou um manifesto interesse pela Retórica e pela Oratória, devoto à actividade pregadora e predicante em muitos trabalhos apostólicos, elevou o género da espiritualidade ao seu máximo esplendor $^{14}$. Contudo, o conjunto das suas produções não se direccionava, exclusivamente, para teólogos ou membros clericais, pois apresenta um espectro bem mais abrangente e ecléctico, que visa tornar a leitura das suas obras acessível a todos aqueles que as queiram manusear ${ }^{15}$. A estética literária de Granada caracterizase ao nível da res pela auctoritas narrativa, a grauitas e profundidade das reflexões filosóficas e ao nível dos uerba distinguese pela breuitas das suas sentenças, a latinitas discursiva, a proprietas verborum et exemplorum, a perspicuitas e clareza das formas. As suas produções tiveram um inegável sucesso, não só aquando a vida do autor como também ao longo dos séculos XVI, XVII e XVIII ${ }^{16}$.

A produção do Dominicano, em particular a tríade Latina que integra a Collectanea Moralis Philosophiae (1571), Silva Locorum (1582) e a Rhetorica Ecclesiastica (1576) - detem a nossa particular atenção por se afastar deste espectro de literatura de espiritualidade aproximando-se mais dos moldes do Humanismo Clássico ${ }^{17}$. No que concerne

Pedro Lain Entralgo, La Antropologia en la Obra de Fray Luís de Granada, Consejo Superior de Investigaciones Científicas, Madrid, 1988.

14 M. Herreo Garcia, «Ensayo histórico sobre la oratória sagrada española en los siglos XVI y XVII» in Sermonario clásico, Escelicer, Madrid, 1942, 27.

15 Juan José Amate Blanco, «La préocupación linguística en fray Luís de Granada. », in Fray Luís de Granada IV centenário 1588/1988, Organizan Dominicos de Andalucia Universidade de Granada, 149.

16 Um êxito comprovado com o Libro de la Oración y Meditación que no seu primeiro ano de publicação contava já com oito edições, justificadas pela rapidez com que se esgotavam. Há até quem afirme que algumas edições integrais das obras de Frei Luís de Granada embarcaram para o Novo Mundo. Vide a este propósito Agustin Turrado, O.P. Director del Colegio Mayor "Santa Cruz la Real", "Granada nel estilo literário de Fray Luis" in Fray Luis de Granada, IV Centenário 1588/1988, Organizan Dominicos de Andalucia, Universidad de Granada, p.159.

17 Collectanea Moralis Philosophiae in tres tomos distributa: quorum primus selectíssimas 
o eclectismo e a diversidade da produção Granadina, não é idóneo tomarmos umas obras como sendo mais importantes do que outras, nem tão pouco discutir a qualidade retórico-literária destas ${ }^{18}$. No entanto, devemos fazer uma distinção clara, precisa e fundamentada quanto à natureza, às características e ao propósito das mesmas. O nosso estudo fará o enfoque sobre a obra de 1571, a única que conta com a presença da herança epistémica de Plutarco e de forma bastante expressiva.

A produção latina apresenta a natureza como topos de eleição, seja a natural seja a humana, tomada a primeira como reflexo da segunda. Desta forma, pretende-se espelhar a labilidade dos ins- tintos humanos, os seus eternos e irresolúveis problemas relacionados sempre com os limites da sua liberdade ${ }^{19}$. Cultor de um estilo eloquente e de um saber enciclopédico, Frei Luís de Granada não concebe a reflexão filosófica fora da dicotomia: limitação humana versus grandeza divina ${ }^{20}$.

Restringiéndonos a su producción latina, cualquiera de sus obras es un buen exponente de ello, pero destacan, en est aspecto, su Collectanea Moralis Philosophiae, la filosofia moral que recoge así como los princípios éticos que deben según el inspirar el comportamento del governante, tanto eclesiástico como civil, en

sententias ex omnibus Senecae operibus. Secundus ex moralibus opusculis Plutarchi: tertius clarissimorum principum \& philosophorum insigniora apophthegmata, hoc est, dicta memorabilia complectitur (1571).Esta obra voltará a ser impressa em $1582 \mathrm{em}$ Paris e em 1775 novamente em Valência; Sylva Lororum qui frequenter in concionibus occurrere solent, omnibus diuini verbi concionatoribus; cum primis utilis \& necessária. In qua multa tum ex veterum Patrum sententiis colecta (1582); Rhetorica ecclesiastica siue de ratione concionandi libri sex (1576). Esta última obra foi traduzida por MANUEL López MuÑoz, Los seis libros de la Retórica Eclesiástica de fray Luis de Granada, edición bilingue y estúdio preliminar, Colleción Quintiliano de Retórica y Comunicación, 2009.

MaRia IdAlina Resina RodRIGUeS afirma a este propósito: «una breve referencia merecen aún das obras de menos interés que cualquiera de las anteriores citadas, pero, no por eso, com toda seguridade, inútiles para los predicadores a quienes se destinaba», in MARIA Idalina Resina Rodrigues, Fray Luis de Granada y la literatura de espiritualidade en Portugal, Madrid, 1988, p.500.

19 Azorín, Los dos Luíses y otros ensayos, Coleccion Austral, Espasa - Calpe, S.A, Buenos Aires, 1944, p.36.

20 «y qué grande se ofrece à nuestra consideración este orador insigne, si meditamos un momento sobre el fondo hermosísimo de sus castizas sermones. Qué conocimiento tan profundo de Dios y del ser humano!Qué filosofia tan consoladora, Y qué nobleza en el pensar, y qué acierto en el discurrir! Sus sermones son libros llenos de sabiduria, donde el hombre aprende à conocer la grandeza de Dios y su grandeza, que es pequeñez junto á la de su creador.», in CAlixto P. Hornero, Elementos de Retórica com exemplos latinos de Cicerón y castelhanos de Frei Luís de Granada para uso de las Escuelas Pias, Madrid, 1815, p 35 
pocos de nuestros autores renascentistas se da en tan alto grado una interrelación entre su obra castellana y la latina, así como entre su obra teórica y su produción escrita. La Collectanea es una obra un tanto peculiar dentro de la producción de fray Luís, un libro de temas de filosofia moral o de antropologia ética, consistente, un repertório de citas de autores clássicos para uso de los predicadores. Se trata de un grueso volumen dividido en três partes independientes, dedicadas la primera a Séneca, la segunda a Plutarco y la tercera a uns serie de autores antíguos y modernos, desde Cicerón a Erasmo"21.

\section{PIO AC BENEVOLO LECTORI}

Excerto1.

Huius igitur tanti uiri consilium sequutus, ex Philosophis omnibus, qui de moribus et recta uitae institutione monumenta aliqua posteritati relinquerunt, duos potissimum (qui uelut duo moralis philosophiae lumina sunt, nempe ex latinis Senecam, ex graecis Plutarchum) mihi praecipue deligendos putaui, quos studiose perlegerem, et insigniores eorum sententias, uelut amoenissimos flores carperem, et in calathis, hoc est, in locis communibus distincte reponerem, quo et quid isti uiri de uirtutibus et uitiis praeclare sensissent, unum in locum congererem, et studiosis lectoribus uelut spectandum proponerem ${ }^{22}$.

Frei Luís de Granada elege estes dois autores - Séneca e Plutarco - por colocarem em palco as subtilezas e complexidades da natureza humana, acentuarem e esbaterem as suas luzes e sombras, seja nos seus vícios e virtudes, seja nas suas verdades e falsidades: princípios reguladores da Collectanea

21 Não conseguiremos neste espaço redimir e esclarecer a taxonomia das obras do Granadino mas a este propósito vide: José GonZÁLEZ VÁzQUEZ, "Valoración de la producción latina del renascimiento Granadino" in Clasicismo en el Renascimiento Granadino, Publicaciones de la Universidad de Granada, 1996, pp. 317-341; Maria Idalina Resina Rodrigues, Fray Luís de Granada y la Literatura de espiritualidade en Portugal, Madrid, 1988; Fray Antonio Garcia (ed), Fray Fray Luís de Granada: su obra y su tiempo in Actas del Congreso Internacional de Granada Servicio de Publicaciones de la Universidad de Granada, vol I y II, Granada, 1993.

22 Tradução nossa: «Portanto, seguindo o conselho deste grande homem, de todos os filósofos que terão deixado para a posteridade alguma produção escrita sobre os costumes de uma vida recta e justa, considero dois os faróis luminares da filosofia moral, a saber: dos latinos Séneca e dos gregos Plutarco. Penso de deveriam ser preferencialmente escolhidos para que sejam lidos detendo a nossa atenção de forma demorada, sentenças até aqui dispersas e agora reunidas e compiladas por lugares comuns, reorganizando o que os homens opinaram de forma clarividente sobre virtudes e vícios e proponho estes pareceres ao estudo e à consideração dos leitores» 
Moralis Philsophiae. Paul Oskar Kristeller sublinha a nossa convicção afirmando que "the essential reward of virtue is virtue itself which makes man happy. For human nature cannot attain anything higher than virtue. The opposite applies to vice ${ }^{23}$ ".

Depois da argumentação a propósito da escolha dos autores do I e II tomos e do convite explícito ao leitor a reflectir, demoradamente, sobre a clarividência de homens insignes, é agora tempo do Dominicano comentar a escolha para a dispositio dos exempla auctorum:

\section{Excerto2.}

His etiam apophthegmata (hoc est, clarissimorum philosophorum, et principum dicta, quae insigniora mihi uisa sunt) eodem ordine, iisdemque locis ad nectenda putaui, propterea quod haec non longis ambabigus, sed arguta breuitate, et dicentium auctoritate, facile et oblectant animos, et uitam instituunt. Hoc igitur opus quod pro rerum uarietate in três tomos diuisimus, hac breuiori forma edendum curauimus, ut hac formula excussus, uelut quidam selectissimarum sententiarum thesaurus, non ad uitae solum institutionem, sed ad oblectamentum quoque studiorum accommodatus, in sinu semper gestaretur, et omni tempore, omnique loco, tanquam leuis sarcina, ad manum inueniretur ${ }^{24}$.

Desta forma e cumprindo as funções retóricas de docere, delectare e mouere, a Collectanea Moralis Philosophiae apresenta três tomos com a seguinte estrutura: o primeiro tomo congrega o legado de Séneca, o segundo contempla os apophthegmata de Plutarco e o último tomo reúne as máximas de vários autores desde Cícero a Erasmo ${ }^{25}$. Sendo

P. OSKar KRISTELler, Renaissance concepts of man and other essays, Harper rand Row, New York, 1971, p. 136.

24 Tradução nossa: Também os apotegmas (isto é, os ditos mais insignes dos mais ilustres príncipes e filósofos) pensei que os devia organizar pela mesma ordem e pelos mesmos lugares comuns, isto é não com largos e desenvolvidos circunlóquios se não com a mais breve e pungente brevidade e com a autoridade dos que os proferem, por um lado deleitam facilmente os ânimos e por outro instruem a vida. Assim, esta obra, dada a variedade de temas, foi dividida em três tomos, preocupámo-nos que viesse à luz com a forma mais breve, como se fosse um tesouro das mais selectas sentenças e apropriadas não só à formação da vida mas também do deleite dos estudos como um manancial sempre acessível.

Primus tomus Collectaneorum Moralis Philosophiae, qui selectíssimas sententias ex omnibus Senecae Operibus per communes locos digestas, continet; Alter tomus Collectaneorum Moralis Philosophiae, qui selectíssimas sententias ex omnibus opusculis moralibus Plutarchi excerptas, ex per communes locos digestas, continet; Tertius tomus Collectaneorum Moralis Philosophiae, qui selectíssima Apophthegmata ad Rectam vitae institutionem conducentia continet; ex clarissimis auctoribus qui hac de re scripserunt, colecta et in locos communes digesta. 
um manancial integral e enciclopédico, que acolhe temas tão diversos, a organização e a dispositio não podia deixar de ser cautelosa e cuidada, de forma a evitar dispersão dos leitores e garantir o seu deleite. Frei Luís amplifica a questão justificando que os topoi não respeitam ordem alfabética para que a arbitrariedade das letras não separe o que a natureza axiológica e filosófica aproxima.

\section{Excerto 3}

Hunc autem ordinem, non autem literarum alphabeti sequuti sumus, ut quae erant inter se tum similia, tum contraria coniungerentur, ne, quae et natura et tradenti ratione coniuncta erant, propter exiguum literarum discrimen separaremus. Constat enim ex philosophorum doctrina, similium idem esse iudicium, et contrariorum eandem esse disciplinam, et inter ante praedicamentorum, ut appellant, regulas, definiuit. Quocirca haec tria locorum genera (quae tantam inter se affinitatem habent) iuxta se reponi, Nec ob tenuissimum literarum discrimen, separari debuerunt, cum praesertim si quid hic subsit incommodi, facile indicibus ordine alphabeti descriptis, eis possit occurri ${ }^{26}$.

Neste ponto, Frei Luís de Granada refina as suas explicações e denuncianos a chave de leitura para a análise da estrutura interna dos tomos. Em todos é visível a mesma metodologia, numa primeira parte reserva-se lugar para géneros e espécies, numa ordem descendente e assimética, desde Deus ao Vulgus - prima classis in qua ponuntur tituli ad diuersa genera statuum et personarum spectantes - e numa segunda parte que contempla os themata relacionados com vícios e virtudes, numa relação mais simétrica e dialéctica - secunda classis locorum communium, in qua de virtutibus et vitiis agitur.

\section{Excerto 4.}

Ut igitur tum ex eo, tum ex Plutarcho, minori negotio maiorem fructum caperemus, operae pretium me facturum putaui, si quid quisque illorum de quaque uirtute uel uitio diuersis in locis scriptum reliquisset, in unum locum coactum, antelegentis oculos ponerem. Quod in Seneca magis

Tradução nossa: Preferimos seguir a ordem já apresentada e não a alfabética para poder unir o que era semelhante entre si e aproximar também os seus contrários, em vez de separar pela arbitrariedade alfabética o que a natureza terá unido também pelo método de ensino. Na verdade, consta pela doutrina dos filósofos que o juízo das coisas semelhantes é o mesmo que estabelece os seus contrários, o método é equivalente. Entre o género e a espécie contiguas, a afinidade é marcada pela forma e o que se atribui ao género é passível de ser atribuído à espécie, segundo o próprio Aristóteles o define. Consequentemente estas três classes de lugares que apresentam tanta afinidade entre si deveriam estar juntas e não separar-se pela levíssima diferença alfabética. 
quam in Plutarcho necessarium fuit, cuius pleraque scripta epistolis ad Lucilum missis continentur, quarum argumenta maxime uaria sunt. Quid enim epistolare argumentum non recipiat? Haec autem tanta uarietas in ordinem aliquem redigenda fuit, quod ipse etiam Seneca monet, qui ea, quae legendo colligimus, meius distincta quam confusa seruari docet. Scio fuisse alium, siue ille Erasmus, siue quiuis alius ementito eius nomine fuerit, qui hunc etiam laborem suscepit et flores ut libri titulus praefert, Senecae collegerit, sed hic (ut omittam quod multa scitu dingissima, quae nos decerpsimus, omisit, quod uoluminis nostri magnitudo facile indicat) tamen is epistolarum et librorum, non locorum, hoc est, materiarum ordinem est secutus. Ita factum est, ut quae confusa et uaerie disiecta ac proinde diffcilia inuentu erant, eodem modo confusa relinquerentur. Hos autem locos, quo res esset dilucidior, in tres classes distinximus, in quarum prima tituli ad uarios personarum status pertinentes, ab ipso Deo optimo maximo exordium capientes, collocantur. In secunda uero virtutum et uitiorum illis aduersatium loci reponuntur. In tertia uero quaedam alia peregrina, quae non ita cum superioribus cohaerebant, collocata sunt. Quia uero christiana religio theologicis uirtutibus principem locum inter omnes alias merito tribuit (de quibus uix ulla apud ethnicos auctores mentio fit) ideo pro illis, uirtutes quasdam theologicis afnes, et uitia eisdem aduersantia substituimus, ut quatenus liceret, theologicarum et cardinalium uirtutum series retineretur.

Portanto, pensei acerca de Plutarco que seria de grande valor o que teria deixado escrito sobre a virtude ou vicio em diversos lugares. E tal foi mais necessário em Séneca que em Plutarco visto que daquele (primeiro) a maioria dos escritos estão congregados nas cartas enviadas a Lucilio, cujos temas são muito variados. Pois, quem não recorre a uma epistola? Esta variedade deveria ser seleccionada e organizada sob uma ordem específica e este não é se não um conselho do próprio Séneca:as coisas devem ser apreendidas isoladamente e não misturadas. Outros houve que a este mesmo labor se dedicaram, seja Erasmo ou algum outro que por essa identidade se faça passar e que da mesma forma reuniu as Flores de Séneca (1554). Este terá seguido a ordem das epistolas e o método de lugares comuns ou temas como este presente. Assim, acontece que o que está disperso e por isso difícil de encontrar se há tornado igualmente confuso. Estes lugares comuns, para que o assunto fosse mais claro, foram separados em três livros, dos quais no primeiro se colocaram títulos que se atêm a vários estados de pessoas, começando 
por Deus todo poderoso. No segundo colocaram-se os lugares correspondentes às virtudes e vícios que se lhes opõem. No terceiro estabeleceram-se matérias várias que não casavam com aquelas mais excelsas. Posto que a religião crista prioriza em primeiro lugar de entre todas as virtudes as teologais (sobre as quais apenas fazem breve menção os autores pagãos) substituímos por outras afins às teologais e seus vícios correlatos para que se retenha, na medida do possível, as virtudes teológicas e cardinais.

Depois de ouvidas as justificações e de apresentadas algumas orientações de leitura da obra, lancemos um olhar sobre o Index Locorum da Collectanea Moralis Philosophiae para conhecermos os themata escolhidos por Frei Luís de Granada e para confirmarmos a sua dispositio no tomo.

\section{INDEX LOCORUM}

ALTER TOMVS

COLLECTANEORVM MORALIS PHILOSOPHIAE, QVI SELECTISSIMAS SENTENTIAS EX OMNIBVS OPVSCVLIS MORALIBVS

PLVTARCHI EXCERPTAS, EX PER COMMVNES LOCOS DIGESTAS, CONTINET

PRIMA CLASSIS, IN QUA PONVNTVR TITVLI AD DIVERSA GENERA STATVVM ET PERSO-

\section{NARVM SPECTANTES}

I. Deus

II. Dei providentia et justitia

III. Dei opificium

IV. Anima rationalis

V. Affectus et passiones animae

VI. Adolescentia. Senectus

VII. Vir et uxor.Matrimonium

VIII. Pater, filius, filiorum educatio

IX. Doctor et auditor

X. Proficientium status

XI. Sacerdos

XII. Rex. Princeps

XIII. Judex. Magistratum

XIV. Acceptio personarum

XV. Respublica

XVI. Potentes.Potentia

SECVNDA CLASSIS, QVAE COMMVNIA VIRTVTVM ET VITIORVM LOCA COMPLECTITVR

XVII. Justitia

XVIII. Usura

XIX. Restitutio

XX. Contumelia. Convitium

XXI. Adulatio, contraque libertas admonendi

XXII. Religio

XXIII. Sacrificium. Oblatio

XXIV. Pietas in patriam

XXV. Observantia in majores

XXVI. Gratitudo in Deum 
XXVII. Contemplatio

XXVIII. Juramentum

XXIX. Mendacium

XXX. Obedientia

XXXI. Liberalitas

XXXII. Avaritia. Prodigalitas

XXXIII. Divitiae.Divites

XXXIV. Paupertas

XXXV. Fortitudo

XXXVI. Fortunae inconstantia

XXXVII. Fortunae utriusque contemptos et moderatio

XXXVIII. Prosperitas

XXXIX. Adversitas

XL. Persecutiones contra viros bonos

XLI. Patientia.Impatientia

XLII. Constantia

XLIII. Temperantia. Intemperantia

XLIV. Luxus

XLV. Abstinentia

XLVI. Gula

XLVII. Ebrietas

XLVIII. Castitas.Celibatus

XLIX. Clementia. Mensuetudo

L. Mansuetudo.Ira

LI. Recreatio sive relaxatio animi

LII. Cognitio sui

LIII. Abnegatio sui vel affectum cohibitio, sive continentia

LIV. Quies sive tranquillitas animi

LV. Inquietudo animi. Curae.Distractio

LVI. Modestia
LVII. Linguae moderatio

LVIII. Ornatus vestium

LIX. Verecundia. Pudor

LX. Philosophia

LXI. Poetice

LXII. Curiositas improbanda

LXIII. Ambitio, contraque honoris contemptos

LXIV. Honor

LXVI. Hyprocrisis

LXVII. Eloquentia

LXVIII. Studium scientiae, discendi ardor

LXIX. Veritas

LXX. Consuetudo

LXXI. Tempus

LXXII. Vita

LXXIII. Mors

LXXIV. Inferorum regio

LXXV. Beatorum mentium regio

LXXVI. Felicitas vera et falsa

LXXVII. Mixtus ex diversis sententiis locus

2. Os niveis de intertextualidade dos Moralia e a recepção dos apopthegmata

A recepção dos apophthegmata a partir dos tratados morais de Plutarco centra a nossa atenção na ars colligendi ac ars translationis: "durante los siglos XVI y XVII la carta de naturaleza tomo un género literário de sentencias, lo ratifican las múltiples obras que al uso circulaban. Su principal característica 
estribaba en ser collectiones y ello hará que en el mismo saco entren tanto sentencias como apotegmas. Por médio de la selección o recompilación, con este género se articula un critério lógico para la reunión de los materiales que formarán una obra. Pronto aparecieron otros critérios nuevos de organización: el más importante se le debe a fray Luís de Granada, que en su obras Collectanea Moralis Philosophiae asumió como motivo de estructuración los 'lugares comunes' un critério este que hunde sus raíces en la retórica y la dialéctica ${ }^{27 "}$.

Assim, Frei Luís de Granada recolhe vários apophthegmata para fundamentar os vários themata da sua Collectanea, a partir dos seguintes tratados morais de Plutarco: De exilio, De doctrina principum, De num. Vindicta, De liberis educandis, de fortuna et uirtute Alexandri, De uirtute morum, De tuenda bona ualetudine, in problematibus, De officio auditoris, De doctrina uirtutis, in politica, de disputationes philosophorum, De officio auditoris, de Doctrina uirtutis, in Politica,De officio auditoris, De profectu morum, De tranquilitate animi, De docenda uirtute, De vitiosa verecundia, De utilitate capienda ab inimicis, De utilitate cap.ex inimico, De discrimine adulatoris et amici, De cohibenda iracúndia, num philosophandum inter pocula, De amicitia in multos difusa, in oratione consolatória, De ódio et inuidia, De bene lateat uiuens, De vitanda usura, De audiendis poetis, De claris mulieribus, De nota Pythagorae, Vtrum grauiores sint animi morbi quam corporis, De curiositate, Cum principibus philosophandi, De virtute et uitio, bene lateat uiuens, De cupiditate divitiarum ${ }^{28}$. $\mathrm{O}$ Dominicano colocou em relevo as obras plutarquistas que concedem maior importância à Filosofia, à Pedagogia e ao ethos político e moral do individuo, orientado no sentido da obediência da razão, ideais conformes aos intuitos da Collectanea Moralis Philosophiae.

Por este facto, temos de alargar a nossa reflexão e colocar ênfase sobre as seguintes questões: quais são as fontes a partir das quais o Dominicano recolhe o legado Plutarquista e quantos são os níveis de intertextualidade. Apesar do Dominicano conhecer e manusear proficientemente Latim e Grego, consideramos pouco provável que se tenha dedicado ao labor de tradução para Latim dos tratados morais de Plutarco, tanto mais dada a profusão de traduções de reconhecidos humanistas que circulavam por toda a Europa. Muitas traduções latinas foram empreendidas sob a égide de Nicolau V, fundador da Biblioteca Vaticana e pela mão de

27

Ángel L.Soriano Venzal, Bases teóricas del estilo sentencioso teatral y otros géneros literários del Barroco, (ms) pp 1-2.

28 O quadro em anexo sistematiza os vários themata do II tomo e os respectivos tratados acolhidos por Frei Luís de Granada. 
Guarino de Verona (1374-1460) - que traduziu pela primeira vez o opúsculo de liberis educandis - de Pier Paolo Vergério - com o tratado De ingeniis moribus (1566). Muitos humanistas traduziram os Moralia para Latim, como Guarino de Verona, Francesco Barbaro, Christophe Longueil ou Erasmo ${ }^{29}$. Houve igualmente traduções para línguas vernáculas e de entre as quais constam a de Niccolo Perotti - que traduziu o De fortuna Romanorum - Giovani Bernardo Gualandi, tradutor para italiano dos Apoftegmi di Plutarco, motti argumenti piacevoli, sentenze notabili (Venezia 1567), Thomas North que traduz em 1579 as Vidas Paralelas, insistindo no interesse cívico das "Lives of the noble Grecians and Romans, ou ainda Francesco Filelfo que se dedicou ao Apophthegmata. De entre as traduções para línguas vernáculas, a edição mais reconhecida é a de Amyot, que inspirou Montaigne e a edição espanhola de Diego Grácian de Alderete $^{30}$.

Interessa-nos olhar para esta questão na ânsia de perceber quais as edições que podiam ter sido seguidas pelo nosso Dominicano. Erasmo traduziu para Latim grande parte da produção de Plutarco e é bastante razoável que Granada o tenha seguido até porque a ligação com o humanista de Roterdão não deve ser subestimada. No I tomo da Collectanea - reservada às sentenças de Séneca - Frei Luís inclui sentenças de Publílio Siro, que eram indevidamente conhecidas por Prouerbiae Senecae até à correcção filológica de Erasmo. $\mathrm{O}$ facto do Dominicano revelar esta correcção na colectânea mostra a sua proximidade com o humanista holandês. Contudo, algumas outras opções devem entrar em consideração, enumeremos por isso algumas edições potencialmente usadas por Frei Luís de Granada: a edição grega saída à luz pelo prelo de Aldus Menucius e dirigida por Demetrius Ducas, reimpressa mais tarde em 1542 em Basileia, largamente corrigida e ampliada com o título específico "multis mendarum milibus expurgata". Estas correcções estão presentes na tradução latina levada a cabo por Xylander $(\mathrm{H}$. Holtzman ), Basilea em 1570, reimpressa em 1572 e em $1574^{31}$. O humanista

29 Vide R. Aulotte, "Une rivalité d'humanistes. Érasme et Longueil, traducteurs de Plutarque", in Bibliothèque d'Humanisme et Renaissance 30, 1968, p. 549-573.

30 Morales de Plutarco, traduzidos de Lengua Griega em Castellana... Impresso em Alcalá de Henares, por Juan de Brocar, MDXLVIII. Cf. Importância das traduções de D. Gracián de Plutarco, Xenofonte, Isócrates, Agapeto, Díon Cássio como património comum da Península Ibérica vide Nair de Nazaré Castro Soares, O Príncipe Ideal no Século XVI e a Obra de D. Jerónimo Osório, Instituto Nacional de Investigação Científica, Coimra, 1994, p.160-167.

31 Esta edição de Wilhelm Xylander, traductor, encontra-se na Biblioteca Geral da Universidade de Coimbra - espólio da Bibioteca Joanina - com a cota: 1-1-10-171/173, com o título completo Plutarchi Chaeronensis Summi philosophi et historici, Vitae Parallelae, seu Comparatae / Guilielmi Xylandri ... interpretatione, postremo recognita, 
médico Gilbert de Longueil publicou em 1542 em Cologne (apud Johannes Gymnicus), uma edição com traduções latinas de muitos tratados plutarquistas, que é especialmente conhecida a partir da edição publicada em 1544, em Paris (apud Michel de Vascosan) ${ }^{32}$. O famoso humanista parisino foi responsável pela primeira versão completa da produção de Plutarco, em Genéve, em 1572, com 13 volumes (seis em grego e sete em latim). Em suma, o interesse a a difusão da obra de Plutarco tanto em Latim como em línguas vernáculas justifica o relevo que Frei Luís de Granada lhe confere na sua Collectanea Moralis Philosophiae.

$\mathrm{Na}$ verdade, fazer o escrutínio seguro deste tipo de influências entre humanistas ou tentar reconstituir a circulação das edições críticas neste período de tantas movimentações geográficas e culturais não só é uma tarefa árdua como por vezes infrutífera. Contudo, mais importantes do que apurar as fontes é reconhecer a qualidade destas produções, sob o ponto de vista da recepção dos autores Antigos, da perenidade e actualidade deste legado e do mérito intelectual destes humanistas, que pelas suas contribuições individuais deixam um património diversificado e uma memória identitária.

3. A conciliação do Paganismo e Cristianismo na Collectanea Moralis Philosophiae: as dialécticas de um programa humanístico comum

As obras estóicas apresentam afinidades com os textos cristãos pois se para o Cristianismo Deus é uma entidade una e perfeita, para o Estoicismo a entidade divina revela qualidades humanamente reconhecíveis e o Homem é a emanação dessas virtudes: "Roman Christianity and Roman Stoicism are fundamentally similar in terms of morality and ethics" $" 33$. Estoicismo e Cristianismo apesar de não serem coincidentes complementamse na afinidade moral que vai ser optimizada nas produções renascentistas em geral e na nossa Collectanea Moralis Philosophiae, em particular ${ }^{34}$.

et quamplurimis locis emendata ad textum graecum. Accesserunt capita unicuique tractatui addita ... cum annotationibus, appendice item ad vitas comparatas, et ternis indicibus copiosissimis

A edição de Michel Vascosanus, Parisiis 1544, pertence ao espólio da Biblioteca Geral da Universidade de Coimbra, com a cota: V.T. 20-10-12. A edição de Vascosan (1572) foi usada por Amyot, na tradução para vernáculo dos Moralia de Plutarco.

3 Runar M. Roman Thorsteinsson, Christianity \& Roman Stoicism : A comparative Study of Ancient Morality, Oxford University Press, Oxford, 2011, p.209.

34 «Au cours du XVI siècle cette situation se modifie : d'une part le problème des rapports entre stoicisme et christianisme change de point d'application ; d'autre part l'éthique n'est plus le seul domaine qui fasse l'object d'héritage»in Pierre-François Moreau, Le Stoicisme au XVI et au XVII siècle, le retour des philosophies antiques à l'âge classique, Albin Michel, Paris, 1999, p.9. 
A Filosofia do Pórtico tem como corolário a ratio perfecta e a realização da natureza humana persistindo no âmbito natural e na aquisição das virtudes matriciais - prudentia, temperantia, iustitia, fortitudo, constantia -, no autodomínio e na aceitação da inexorabilidade do fim. No imanentistmo estóico, Deus existe em tudo o que é tangível, sob a concepção do universo perfeitamente ordenado com o fito da ars bene vivendi. O Cristianismo, por seu lado, apresenta um programa teológico no plano do mistério, da revelação e do sobrenatural, uma ordem que diviniza o Homem e o eleva no seguimento de determinadas conductas. Pierre-François Moreau preconiza um sistema neoestóico que define da seguinte forma: « ce neoestoicisme tend aussi à constituer un stoicisme chrétien, il faut une philosophie à la religion chrétienne et elle doit être trouvée dans un renouvellement de la philosophie antique $\gg{ }^{35}$.

François Buisson no seu Répértoire des Ouvrages Pédagogiques classifica a obra granadina como uma obra de "Dialéctica e Filosofia"36. Assim, assente neste edifício teológico-filosófico e a partir do Index Locorum - anteriormente apresentado- construímos uma taxonomia para os themata apresenta- dos na Collectanea e em particular no II tomo, referente a Plutarco: a) Binómios Dialécticos ou Agónicos com a mesma raíz etimológica - patientia /impatientia; temperantia/intemperantia - e com diferente raíz etimológica-prosperitas/aduersitas; b) Binómios de Consecutio - Filius/Pater, Princeps/Rex; c) Binómios de Contiguidade - Clemential Mansuetudo; Verecundia/Pudor. No quarto grupo deixamos os binómios que se tecem entre o verdadeiro e o falso, o bom e o mau - Conscientia bona et mala, Amicitia vera et falsa, felicitas vera et falsa ${ }^{37}$.

A Collectanea Moralis Philosophiae ainda que dividida em três tomos parcialmente autónomos e independentes não deixa de apresentar uma unidade e coesão internas na na sua articulação filosófica e a coesão argumentativa. Transversal aos três tomos, sabemos que na primeira parte se reúnem sentenças que dizem respeito a entidades personificadas - prima classis, in qua ponuntur tituli ad diversa genera statuum et personarum spectantes - a segunda parte organiza máximas sobre vícios e virtudes - secunda classis, quae communia uirtutum et uitiorum loca complectitur. $\mathrm{Na}$ verdade, se quisermos concretizar a representatividade dos topoi relacionados com vícios e as virtudes (corres-
35

36 F. Buisson, Répertoire des ouvrages pédagogiques du XVI siècle, Nieuwoop, B. De Graaf, Paris, 1968, p.333.

37 Esta tábua classificativa é da nossa autoria como leitura interpretativa e hermenêutica da obra. 
pondentes a 118 sentenças) ${ }^{38}$, compilados exclusivamente na secunda classis do tomo de Plutarco ${ }^{39}$, concluímos que ocupam $79 \%$. Por este facto, tornámos a virtus estóica ${ }^{40}$ o primordial critério de análise pelo qual se deve pautar a leitura de qualquer um dos tomos : "y en efecto, enaltecer la virtude, combatir el vicio, encender el fuego de la caridade $n$ los corazones y mostrar al hombre em amino que conduce á Dios, he aqui los hermosos ideales que cosntituyen el fondo de la oratória del Cicerón Cristiano ${ }^{41 "}$.

O autor explicita na sua carta introdutória que um corpus deste género dá a liberdade ao leitor de admirar e deleitarse com o que melhor lhe aprover, seja na discussão de um topos em particular, seja na solenidade das sentenças ou eclectismo de autores, seja na reflexão das doutrinas e na amplitude dos preceitos que sendo pagãos parecem cristãos. Ouçamos as palavras do autor a este respeito:

\section{Excerto 5}

Qua obseruatione sit, ut qui collectanea nostra legit, non cen- tones Senecae, sed ipsum senecam continenti pene oratione fluentem, legere videatur. Atque hoc ipsum, simili ratione duc$t i$, in Plutarcho fecimus, quem nunc paucis commendare non est animus, cum ipse se amplitudine et maiestate sua commendet, et iuxta prouerbium, uino uendibili suspensa hédera nihil sit opus, alius ineo grauitatem sententiarum, alius multam maximeque uaiam omnis generis auctorum lectionem, et historiarum cognitionem mirabitur, ego uero praeceptorum sanctitatem, et doctrinae sinceritatem in eo ita demiror, ut cum illum quibusdam in locis (praesertim ubi de profectu morum, de cohibenda ira et uitiosa uerecundia, et cupiditate diuitiarum, de auditoris officio, et tranquillitate animi lego) non Mihi ethnicum philosophum, sed christianissimum instituendae uitae magistrum legere uidear, adeo se ad singularia praecepta, et uaria aduersus uitiorum pestem remedia tradenda, insinuat, atque

38 Vide a propósito Daniel Babut, Plutarque de la vertu éthique, Société d'édition «Les Belles Lettres», Boulevard Raspail, Paris, 1969; François Funrmann, Les images de Plutarque, Thèse pour le doctorat présentée à la Faculté des Lettres et Sciences Humaines de l'Université de Paris, Paris, 1964;

39 Secunda classis, quae communia virtutum et vitiorum loca complectitur.

40 Cf. Daniel Babut, Plutarque et le stoicisme, Presses Universitaires de France, Paris, 1969, pp 37 e sqq. Daniel Babut, Plutarque et la vertu éthique, Les Belles Lettres, Paris, 1969; Mireille Armisen-Marchetti, Sapientiae Facies: étude sur les images de Sénèque, Les Belles Lettres, 1989, Paris.

41 Eduardo CARo, El tercer centenário V.P.Maestro Fr. Luis de Granada, relacion de su vida, sus escritos y sus predicaiones, in Publicación quincenal des Artes, Letras y curiosidades granadinas, Imprenta de Bernardo Bartuilli y Garcia, Madrid, 1888. 
demittit. Iam uero in similitudinibus ad ea quae exponit afferendis, nescias frequentior ne sit, an mirabilior, ut cum in aliis doctrinae partibus ceteros uincat, in hac seipsum superandi locum non reliquerit. Quo nomine haud scio, an is concionatoribus quam Seneca sit utilior, propterea quod similium usus ad populi captum cum primis sit accommodatus. Quod quo euidentius, uel rudioribus etiam apparert, nos similia in marginibus, sicut grauires sententias adnotandas duximus, quo dormitantem lectorem rei pulcherrimae annotatione excitaremos. Sinceritas uero doctrinae eius tanta est, ut in hac parte ipso Seneca uirtutis studiosissimo su- perior mihi esse uideatur. Seneca enim stoicorum errores mordicus tuetur, apathiam et Fatum inducit, omnia honesta paria, similiter et turpia esse contendit, in sola nudaque uirtute summum quidem bonum, sed rectíssima ad illud uia sit, tum etiam manus sibi afferre adeo non damnat, ut interdum etiam probet, certe in Catone ita laudat, ut ex eius uulnere plus gloriae, quam sanguinis manasse dicat. Horum nihil in Plutarcho deprehendes, sed omnia fere purgatissimae rationi et naturae lumini consentânea, fortasse quoniam euangelio Christi eius saeculo latius coruscante, maior humanis mentibus ueritatis lux addita esset ${ }^{42}$.

42 Tradução nossa: “Quem quer que leia a nossa compilação não lerá fragmentos de Séneca mas antes um discurso fluente e quase ininterrupto. Também isto cumprimos em relação a Plutarco, servindo-nos do mesmo método pois não é de nosso interesse recomendar este autor em parcas palavras mas difundi-lo pela sua amplitude e dignidade. Uns admiram a solenidade das suas sentenças, outros o seu eclectismo de leitura de múltiplos autores e conhecimento de várias histórias, mas eu admiro a santidade dos seus preceitos e a sinceridade da sua doutrina, sobretudo quando nos referidos lugares profectu morum, de cohibenda ira, uitiosa uerecundia, cupiditate diuitiarum, de auditoris officio, tranquillitate animi. Dá-me a sensação de estar a ler não um filósofo pagão mas um mestre cristão sobre a instrução da vida a tal ponto que penetra e chega a expor preceitos singulares e remédios vários contra os vícios. E quando radica em símiles e recorre a exemplos para o expor, não sabes se é mais prolixo se admirável, pois supera os outros na sua doutrina. Nem sei se inclusivamente não é este mais útil aos predicadores do que Sèneca pois o uso de símiles adequa-se mais do que tudo à sedução do povo. Mantemos nas margens referências aos símiles como se anotássemos as senteças mais importantes a fim de estimular o interesse do leitor para os assuntos mais belos. A sinceridade da sua doutrina é tal que me parece superar Séneca pois este defende tenazmente os erros dos estóicos, introduz o topos da apatia e do destino. Na virtude inculca o sumo bem do homem sendo que esta não é o sumo bem mas antes o caminho mais recto para tal. Por outro lado, em relação ao suicídio não só não condena como aprova. Em Plutarco tudo é conforme à mais limpa razão e à luz natural talvez porque no seu século ao brilhar o evangelho de Cristo maior é a luz da verdade que é dada às mentes humana". 


\section{A Virtus em Plutarco: a definição do topos a partir do corpus da secunda classis do II tomo}

A edição latina a partir da qual são coligidos os Moralia do autor grego, nunca é especificada pelo Granadino - seria necessário um trabalho de exegese textual para apurar a(s) sua(s) fonte(s), como já vimos - no entanto é dada a informação ao leitor dos respectivos tratados morais de onde se extraem os apoftegmas. A selecção e organização dos variados trechos de Plutarco segue o critério lógico de coesão argumentativa e da unidade estético-literária. Olhemos o corpus:

\section{Excerto Moralia, De liberis edu- candis}

Generaliter equidem, quod de artibus ac scientiis dicere consueuimus, idem etiam de uirtute dicendum. Tria esse quae ad operis perfectionem rite obeundam concurrere oporteat, naturam, rationem, et consuetudinem. Rationem, disciplinam uoco, consuetudinem uero, exercitationem. Initium a disciplina, usus ab exercitatio et meditatione fiet. Ex omnibus autem absolutio comparabitur. Sin istorum pars ulla defecerit, necesse erit hanc claudam esse uirtutem. Caeca enim res est sine disciplina natura et absque natura disciplina manca res existit. Imperfectum autem quiddam existit, si ambobus his careat exercitatio. Nam sicut in agrorum cultura, bonam in primis sse tellurem oportet, tum ferendi peritum agricolam, dehinc optima semina, eodem modo telluri naturam, agricolae praeceptorem, seminibus studiorum institutiones atque praecepta conferes. Quae omnia in eorum animos conuenisse ac sprasse contenderim, quos uniuersi decantant, Pythagoram dico, Socratem, Platonem, et quisquis sempiternam consecutus est gloria. Ingetis certe felicitatis et diuini fauoris est, sicui singula haec Dii contulerunt. Cum Demetrius captam urbem soloaequasset, Stilponem interrogauit, nunquid suorum quicquam amisisset? Cui Stilpon, haud equidem, inquit, bellum enim nulla ex uirtute spolia ducit. Concors huic et consentaneum illud Socratis uidetur esse responsum. Nam cum Gorgias, ut arbitror, percontaretur, na Persarum regem felicem esse putaret. Nescio, inquit, quantum habeat uirtutis atque disciplinae, perinde ac in hisce, non autem fortunae bonis persistat beatitudo.

No geral, o que sabemos dizer sobre as artes e as ciências, também o há que dizer em relação à virtude. São três os aspectos que devem concorrer para se chegar devidamente à consumação de uma acção: natureza, razão e costumes. Chamo razão à instrução e costume à prática. Os inícios correspondem à instrução; a prática do exercício e da preparação. A perfeição plena provém de todas elas. Se faltar algumas destas três, a virtude andaria coxa. A natureza sem instrução é cega, e a instrução sem 
natureza é algo defeituoso. Por seu lado, o exercício é nulo se carece de ambas. Da mesma forma que o cultivo dos campos precisa que primeiro a terra seja boa para que o agricultor a possa cultivar, por último também são necessárias boas sementes. Assim compararás a natureza à terra, o mestre ao agricultor, os preceitos às sementes. Creio poder afirmar que tudo isto concorre e palpita nas almas das pessoas que todos enaltecem, seja Pitágoras, Sócrates ou Platão numa afamada imperecibilidade. Cada um deles tem a felicidade e o favor divino se os deuses the tiverem outorgado cada uma destas coisas. Quando Demétrio arrasou aquela cidade, perguntou a Estilpo se por acaso havia perdido algum dos seus bens. Estilpo ter-lhe-á dito "de forma nenhuma, pois não há nenhuma guerra que possa expoliar a virtude". Concorde a este também parece ter sido a resposta de Sócrates. De facto, quando Górgias, segundo se crê, lhe perguntou se acreditava que o rei dos persas era feliz respondeu: "desconheço se tem alguma virtude ou instrução" como se apenas nisto e não nos bens da fortuna residisse a felicidade.

Excerto Moralia: De utilitate cap. ex inimico

Vniuersum aurum quod uel super terram est, uel sub terra, non est aequiparabile uirtuti, ueluti inquit Plato. Illud etiam Solonis dictum sempre conueniet in promptu habere. At nos, inquit, uirtutis diuitias cum illis non commutabimus, nec acclamationibus epulo conducta multitudinis, nec honoribus summoque accubitu apud eunuchos, concubinas, et satraparti uxores. Nihil enim suspiciendum, nec praeclarum, quod ex turpitudine nascitur

"Todo o ouro, que existe na terra e debaixo dela não é equiparável à virtude" tal como disse Platão. Mais, convém sempre ter presente o dito de Sólon: "Nós não trocaremos como aqueles, os bens pelas virtudes, nem pela aclamação da multidão que se governa por prazeres, nem pelas honras, nem pelo lugar mais tentador ao lado dos eunucos, às concubinas e esposas. Pois não se deve almejar nada que nasça do vício".

\section{Excerto Moralia De lib.educandis}

Quemadmodum corpus non solum incolume, uerum etiam bonae habitudinis esse oportet, ita et orationem non modo non aegram, sed etiam robustam esse conuenit. Nam quicquid tutum est, id solum modo collaudatur. Quod nero cum periculo sit, id etiam admiratione prosequimur. Eandem quoque de animi dispositione sententiam habeo. Nam neque temerarium, nec audacia prorsus exutum ac timidum esse decibit, cum illud quidem impudentiam, hoc autem seruilem afferat turpitudinem. Mediam autem in cunxtis secare uiam, summae et artis et consonantiae est.

Assim como convém que o corpo esteja são e de bom aspecto, da mesma maneira o discurso pretende-se fértil, 
robusto e vigoroso. Tenho a mesma opinião sobre a disposição da alma pois não convém que seja temerária, nem que seja despojada de audácia, ou seja tímida, pois se um leva à imprudência, o outro a uma servil vergonha. Seguir em tudo o meio termo é o melhor método e a melhor consonância.

\section{Excerto Moralia De officio auditoris}

In literis discendis, in musicis, ac luctandi arte exordia multum exhibent laboris et difficultatis imodica obscuritate, uerum progresso paulisper, facilia cognitu fiunt omnia, et amibilia quae et gesserit et dixerit. Itaque uelut cum homine ignoto, magna mox intercedit beneuolentia et familiaritas, simul atque in mutuam uitae consuetudinem transieris, ad eum sane modum, in ipso philosophiae uestibulo non dees insoliti quippiam, quo torqueare. Atqui negligenda haec sunt, atque adeo non tanti aestimanda, ut metu et animi deiectione moxin limine $a b$ instituto resilias. Sedstrenue tentanda res est unaquaeque, recordatione dulcedinis, quae blanditur tendentibus porro, ac suauia facit omnia quae sunt pulchra. Veniet enim ita multo post lux quaedam simul cum disciplina, sumum ingerens amorem et illecebras ad nirtutem.

Assim os primeiros ensinamentos na leitura e na escrita, na lira e na hasta pública suscitam muita confusão, esforço e incerteza para aquele que progride gradualmente da mesma forma que as suas relações com os homens, a familiaridade e intimidade são desejáveis como a iniciação na filosofia, exigindo empenho e entrega. Não há que desanimar e com persistência empreender os seus princípios para que depois se veja a luz na aprendizagem, produzindo um grande amor e atracção pela virtude.

Frei Luís de Granada selecciona os apoftegmas de Plutarco, a partir dos seus vários tratrados morais e dispõe-nos num corpo de texto único, contínuo e lógico, cumprindo com a promessa feita na carta introdutória: não iria apresentar o legado do autor de Queroneia de forma dispersa e fragmentada. A argumentação a propósito da realização da virtude tece-se numa tríade: natura, ratio, consuetudo e em torno gravitam ainda a disciplina, exercitatio e meditatio. Se a razão se correlaciona com a instrução, os costumes, por sua vez, imbricam-se na prática. Esta analogia, recuperada por muitos humanistas compara a terra à natureza, o agricultor ao mestre $\mathrm{e}$ as sementes aos preceitos e ensinamentos, elementos, que isoladamente se invalidam uns aos outros mas que combinados e em consonância promovem a perfeição na sua plenitude.

As sentenças plutarquistas recorrem ao método retórico da amplificatio, através da enumeração de exempla e analogias que reforçam a argumentação mas também pela constante invocação dos ditos e Sócrates, Platão, Górgias, Sólon que num segundo nível de citação ilustram e fundamentam a elocutio dis- 
cursiva, imprimindo grauitas e auctoritas $^{43}$. O teor pedagógico, o carácter didáctico e o potencial mnemónico da obra são veiculados a partir de todos estes exempla, da construção de comparações, metáforas e alegorias, que convidam o leitor à descoberta e interpretação da mensagem, seduzido pelo requinte e elegância da forma mas também pelas virtualidades heurísticas e ecfrásticas da substância $^{44}$.

O Homem depara-se com todas as suas dialécticas interiores - passiones animae versus Virtus - e exteriores Fortuna versus Natura - e sabe que apenas conhece o caminho ascendente da stultitia à sapientia por intermédio da philosophia ${ }^{45}$. Importa sublinhar que apenas pela acção do bem e da razão, pela prática da verdade, o Homem resgata e legitima a sua condição éticomoral e se emancipa da condição mortal. Deus está para a matéria do universo como a alma para o corpo humano e o Homem apenas consegue aceder à alma pela razão divina, ultrapassando do plano contingencial. O divino surge, intrinsecamente, na essência humana como expressão eminente de toda a racionalização. Na verdade, o Indivíduo sente-se por natureza ou exigência interior imbuído para o aperfeiçoamento moral e para um bem maior, absoluto, total, eterno, "a passagem ao Logos perfeito consuma-se na medida em que a luz divina, anelada na origem do homem o ilumina ${ }^{46}$ ".

O edifício filosófico do (neo)estoicismo defende como um dos seus pressupostos mais nevrálgicos a progressão e a superação humanas que elevam o Homem, que o fazem aprender as virtudes desaprendendo os vícios, tendo a imagem de Deus como corolário do paradigma da imitação. A aproximação a Deus consuma-se quotidianamente amando todos os homens mesmo os escravos e inimigos, sabendo saciar o

43 Terence CAVE, Cornucopia - Figures de l'abondance au XVI siècle : Erasme, Rabelais, Ronsard, Montaigne, Macula Collection Argo, Paris, 1997; Antorne Compagnon, La seconde main ou le travail de citation, Éditions du Seuil, Paris, 1979.

Sara Newman, "Aristotle's Notion of «bringing-before-the-eyes» its contributions to Aristotelian and contemporary conceptualizations of Metaphor, Style and Audience", in RHETORICA - A journal of the History of Rhetorica, volume 20, number1, University of California Press for International Society for the History of Rhetoric, 2002, pp. 1-23; Frances Yates, L'art de la mémoire, trad. De l'anglais par Daniel Arasse, Paris, 1975.

Mireille Armisen-Marchetti, Sapientiae Facies - études sur les images de Sénèque, Les Belles Lettres, Paris, 1989; da mesma autore vide ainda "La philosophie selon Sénèque: apprentissage ou révélation", in Révélation et Apprentissage dans les texts grecs et latins, Centro de Estudos Clássicos da Faculdade de Letras da Universidade de Lisboa, 2012.

46 Bernardo CorrêA D’Almeida, “A civilização do amor Segundo Séneca e João Evangelista", in Brotéria: Cristianismo e Cultura, vol. 174, Maio/Junho, 5/6, Revista Publicada pelos Jesuítas portugueses, 2012 
pobre, socorrer o náufrago e ajudar os desfavorecidos. Daqui se infere que viver segundo a ratio perfecta não é viver para si mesmo mas no sentido do outro, um elo que deve ser indivisivel, porque a solidariedade veicula e interliga a Humanidade, fá-la crescer em unidade total da razão.

O modus operandi da obra granadina floresce neste anseios humanistas, na tentativa de redimensionar o Homem, incitando-o a olhar para si mesmo na redescoberta da sua condição dual, consciencializado-o das suas falibilidades e fraquezas, da sua dimensão polimórfica e contraditória, da sua grandeza e da sua miséria, da sua lucidez e da sua cegueira, da sua bondade e da sua maldade, não fosse isso o que lhe confere liberdade e sobretudo o suo verdadeiro Humanismo. O movimento dialéctico de Logos imperfeito/perfeito desdobrado em tantos outros pares agónicos reforçam esta construção granadina de entidades que se digladiam mas que têm nesta sua antinonimia o próprio funcionamento e organicidade: vício/virtude, corpo/alma, Homem (emanação divina)/ Deus(Origem), Luz/sombra, interior/ exterior. Contudo, o Homem não vive exclusivamente na assimetria destes conceitos e Frei Luís de Granada abre um espaço, intermédio, mediador e de- miúrgico, um espaço que amplifica a nossa acção e livre arbítrio já que entre a Stultitia e a Sapientia está a Philosophia, entre a Virtus e o Vitium está a Tentatio, entre a Vita e a Mors está o Tempus. Encontramos estes como os Baluartes da Collectanea Moralis Philosophiae e propomos-nos olhar os apoftegas de Plutarco que entrelaçam esta triologia: Vita, Tempus e Mors.

VITA

Tidid magnanime, inquit Homerus, quid genus percontaris?, cuiusmodi est foliorum genus, huiusmodi et hominum. Foliorum alia quidem uentus decutit, alia pullulans fert silua, uerno autem nascuntur tempore, sic uirorum genus, hoc quidem nascitur, hoc uero desinit ${ }^{47}$. Hesiodus Homero et existimatione et tempore posterior, Pandoram indicat dolium aperientem per omnem terram ac mare malorum copiam dispersisse, sic dicens. At mulier manibus magnum auferens operculum, hominibus curas suo consilio praebuit perniciosas, sola uero spes in aedibus infrangibilibus intra dolium sub labris permansit, nec foras euolauit, dolio enim prius opposuit operculum, ast alia innumera in homine exilierunt mala. Plena

47 II tomo, secunda classis, Plut. Moralia, In oratione consolatoria: Magnânimo filho de Tideu, disse Homero, porque me perguntas a minha linhagem? Igual à linhagem das folhas assim é a dos mortais. Da mesma forma, umas folhas leva-as o vento e dispersa-as pelas terras, outras florescem nos bosques, brotando na estação da Primavera. Assim é a linhagem dos homens, um nasce e outro perece. 
enim malis tellus, refertum mare, morbi autem hominibus quotidiani. Hi noctu sponte accedunt, mala mortalibus tacite aferentes, quandoquidem uocem abstulitur consultor Iupiter ${ }^{48}$.

\section{MORS}

Quid mirum si fissile fissum est?, si quod liquescere potest, delicuit?, si quod exuri potest, combustum est?, si corruptibile, corruptum?, quando enim in nobis ipsis non est mors? Et, ut inquit Heraclitus, idem uiuens et mortuus, uigilans et dormiens, nouum et uetus, quae enim recidere, illa sunt, et illa rursus quae cecidere, haec. Nam ut ex eodem luto potest quispiam animalia fingens, confundere, et rursos fingere ac confundere, atque hoc uicissim incessanter facere, sic et natura exe adem materia iandiu quidem nostros aedidit auos, et continuo poste os genuit parentes, mox nos, deinde alios ad alios circulari quodam modo producet, et hic nascendi fluuius perpetuo fluens, nunquam quiescet, et rursus qui huic opponitur, moriendi, sie Acheron a Poetis, siue Coci- tus appellatus. Quo circa nostrum hoc uiuere, fatale quoddam debitum esse dicitur, utpote reddendum, a proauis nostris mutuos acceptum, quod facile ac citra gemitum restituendum est, cum a quo accepimus, exigitur. Hocenim pacto uideri gratissimi poterimus. Existimo autem naturam ipsam, cum tantam uitae breuitatem nullo ordie uidisset, ut mortis terminus lateret, uoluisse. Hoc enim fuit melius. Nam si praeuidissemus, nonnulli maeroribus contabuissent, et ante mortem decessissent. Aduerte autem uitam ipsam, cum doloribus refertam, tum multis solicitudinibus exhaustam, quas si reecensere uellemus, uehementer ipsam condemnaremus, et quae apud quosdam obtinuit, ueram opinionem redderemus, quod scilicet longe sit melius mori, quam uiuere. Itaque Simonides, hominum inquit, modicae quidem uires, inanes uero curae, uitaeque breui labor supra laborem, et mors crudelis atque ineuitabilis imminet. Illius enim aequalem sortiti sunt portionem, et boni, et quicunque est malus ${ }^{49}$.

II tomo, Plut., Moralia In oratione consolatoria: Hesíodo, posterior em tempo e fama a Homero, mostra que Pandora ao abrir o presente dispersou pela terra e mar uma multidão de males e disse: "Contudo a mulher reteve com as suas mãos a enorme tampa, oferecendo, intencionalmente aos homens tristes preocupações. Ali dentro reteve apenas a indestructível esperança. No entanto, outras inumeráveis desditas vagueiam entre os homens, pois a terra está repleta de malas, doenças. Estas aproximam-se dos mortais durante a noite de forma natural e silenciosamente já que o prudente Júpiter lhes tirou a voz".

II tomo, Plut., Moralia, In Oratione consolatoria: O que pode suscitar admiração no facto daquilo que tem teor separável ser separado, daquilo que tem teor solúvel ser dissolvido, 
Socrates similem esse mortem dicebat aut profundíssimo somno, aut peregrinationi longae ac diuturnae, aut cuidam corporis atque animi ineritui, proptereaque nihil mali esse in morte. Singula sic percurrens ostendebat. Si enim somnus est aliquis mors, et dormientibus nullum est malum, constat ne mortuis quidem ullum esse malum. Atque quod suauissimus sit somnus profundissimus, quid opus est dicere?, cunctis enim hoc exploratum est. Testatur et Homerus de ipso somno dicens. Profundus, dulcissimus, morti assimilatus. Multi autem in locis et haecdicit. Ibi somno occurrerunt mortis frati. Somno et morti gemellis facie atque aspectu, eorum similitudinem indicans. Gemella enim máxime similitudinem ostendunt. Oppido autem quam sapienter Cinicus Diogenes somno deditus, uitamque relicturus, excitante ipsum medico, et num molestiae quicquam ipsiinesset percontanti, nihil molestiae Mihi inest, respondit, fretem enim frater praeuenit, somnus uidelicet mortem. Quod si peregrinationi assimiletur mors, ne sic quidem malum est, nunquid autem e contrario bonum? Nam corpori inseruire, atque ipsius affectibus adimpletur nugis, felix ne quid, ac beatum? Immensa manque nobis, inquit Plato, ob necessarium alimentum praebet negotia corpus, neque enim quicquam aliud praeter bella et seditiones, pugnasque corpus continet, et quae ab ipso proueniunt cupiditates. Nam propter pecuniarum possessionem omnia excitantur bella, pecunias autem corporis cuasa cogimur comparare, huius obsequiis inseruientes, et ex hoc nullum ob haec omnia philosophiae otium datur $^{50}$. Scitum est illud Archelai,

naquilo que tem teor combustível ser queimado, daquilo que tem teor destrutível ser destruído? Pois como não pode estar contida em nós mesmos a própria morte? Como disse Heraclito, a vida e a morte são uma e a mesma coisa, como a vigília e o sono, o novo e o velho, pois o que perece logo renasce e o que é vivo logo perece. Da mesma forma, o mesmo barro pode modelar figuras, desfazê-las e voltar a moldá-las de novo e fundi-las, repetindo ininterruptamente. Assim, a natureza de uma mesma matéria fez surgir os nossos antepassados, os nossos pais, depois nós e de forma cíclica produzirá os próximos. Este rio de nascimentosfluirá sem interrupções, nunca parará assim como o rio da morte, que flui no sentido contrário. Por isso também se diz que a vida é uma dívida imposta pelo destino para que seja pago o que tomaram emprestado os nossos antepassados, dívida que deverá ser paga de boa vontade quando for reclamada. Penso que a natureza se terá salvaguardado ocultando o dia da morte e assim é melhor. Doutra forma, alguns consumir-se-iam por pena e morreriam antes de chegar à morte. Adverte que a vida está cheia de inquietudes e que ao enumera-las com segurança condenar-nos-iamos. Assim disse Simónides: "as forças dos homens, na verdade, são escassas e inúteis seja ele um homem bom ou vil".

II tomo, Plut., Moralia, In Oratione consolatoria: Sócrates dizia que a morte é semelhante a um sono profundo ou a uma viagem longa e duradoura. De facto, pois se a morte é como 
hoc, inquit, quod malum dicitur mors, solum ex iis quae putantur mala, praesens quidem neminem unquam dolore affecit, absens uero atque expectatum maerorem affert. Nam procul dúbio nonnulli propter imbecillitatem, et eam, quae morti infertur, calumniam, ne moriantur, obeunt. Pulchre igitur Epicharmus, concretus, inquit, est et discretus, et rursus abiit unde uenerat, terra quidem in terram, spiritus ad supera, quid horum graue, ac difficile?, nihil ${ }^{51}$.

\section{TEMPUS}

Quid est, quod Romani Ianuarium principium anni faciunt? Antiquis enim temporibus Martius primus omnium numerabatur, quod cum multis signis perspici potest, tum eo maxime, quod quintum a Martio, et sectum, et reliquos deinceps usque ad extremum a Martio numerant. Quidam dicunt, Martium a Romulo primum omnium fuisse numeratum, quod homo acer atque bellicosus, atque adeo bellandi amore insanus, Marte satum se esse existimans, parentis sui cognomen ceteris mensibus praeponendum esse censuit. Numa Pompilius deinde uit pacatus, et pacis atque otii studiosus, cum ciuium animos a bello ad agriculturam traducere contendisset, Ianuario inter menses principatum dedit, et Ianum, quasi ciuilem, et agriculturae magis quam rei belli studiosum ad summos honores cultumque prouexit. Sed uide ne Numa Pompilius magis consentaneum naturae, quantum ad nos attinet, principium anni sumpserit. Omnino enim eorum quae in circulo circunferuntur, nihil est, quod natura aut extreum sit, aut primum, sed lege factum, ut alii aliud statuant anni principium. Optime uero, qui post hibernum tropicum, annum inchoant, cum sol finem ulterius progrediendi faciat, rursus ad nos se recipit. Fit enim naturale quodammodo huiusmodi principium, quo et lucis tempus nobis augetur, tene-

um sono e nada há de mal para os que dormem é obvio que não haverá nenhum mal para os que morrem. Que necessidade há em afirmar que o sono mais profundo é o mais doce?certamente, isto é o mais evidente para todos. Também Homero o reitera quando afirma que o sono mais profundo, e doce é semelhante à morte. Muitos outros lugares o reafirmam. [...] Mas se a morte se assemelha a uma viagem nem por isso pode ser um mal. Acaso, por contrário, será um bem, servir um corpo e viver com as suas paixões? Grande atenções nos requer o corpo, pela necessidade de alimentação e da possessão de todas as riquezas razão pela qual surgem as guerras e nos vemos obrigados a procura-las para satisfazer o corpo, além dos desejos que provêm da essência dele mesmo.

II tomo, Plut. Moralia, In Oratione consolatória: É conhecido o que proferiu Arquelau de Mileto: Isto que se considera um mal, a morte, de entre os que se têm como males, é o único que estando presente não produz dor mas ausente e esperado produz pena. Na realidade, para muitos a causa e o medo da morte finda-se nos esforços que realizam para não morrer. Epicarmo afirma: Compôs-se e decompôs-se, voltou ao lugar de onde veio, da terra o que é da terra e o espírito ao alto. Pois que há de preocupante e aterrador nisto? Nada. 
brarum uero et noctis diminuitur, princeps denique et substantiae fluxae autor propius accedit ${ }^{52}$.

4. Em tom de conclusão: baluartes filosóficos da Collectanea Moralis Philosophiae - VITA, DEVS, SAPIENS, TEMPVS, MORS

"Esperamos, pois, Bloom, que cresças e que crescendo vás directo à realidade e não pares.

Porque não basta encostares-te aos acontecimentos, o que pensámos para ti é bem mais profundo,

não basta conheceres sete teorias, terás que subir as sete altas montanhas.

E atravessar ainda os continentes como se a terra fosse uma extensão temporal capaz de medir os teus dias"

Gonçalo M. Tavares Uma Viagem à Índia

\section{A Collectanea Moralis Philoso-} phiae é um edifício construído, primorosamente, que não descura o mais ínfimo pormenor, desde os fundamenta hominis. Desta forma, os apoftegmas de Plutarco constituem uma memória imperecível, uma identidade comum que confere universalidade e actualidade à obra do
Granadino. Neste encontro anacrónico, os dois autores revelam em uníssono a preocupação pela dimensão mais antropológica do Homem, enquanto objecto do devir e fruto do Tempo mas com a imprescindibilidade de cumprir com as suas funções de homo eloquens, homo beatus e homo sapiens ${ }^{53}$.

Nos alicerces da Collectanea temos o reconhecimento da natureza dual e controversa do Homem, regenerada nesta dialéctica tentada ora para o vício - com a inflamação do affectus passiones animae - ora no caminho recto da virtude e da ratio perfecta. $\mathrm{O}$ ideal da sapientia, enquanto emanação divina, é o propósito e a aspiração do Homem estulto, empenhando-se no estudo e exercício da philosophia. Esta espiral é accionada pelo Tempo, que sendo revelador do sentido da vida, enfatiza a qualidade dos momentos em detrimento da sua duração. Frei Luís de Granada não alimenta nesta Collectanea a pretensão de irradicar affectus et passiones animae mas desenvolve antes um

II tomo, Plut.Moralia, In Problem.: Porque razão assumem os Romanos como início do ano o mês de Janeiro? Tempos houve em que março se contava como o primeiro de todos. Alguns afirmam que março conta como o primeiro de todos porque tendo sido um homem duro e aguerrido e de certa forma até apaixonado pela luta, por consequência de Marte, pensou-se que o nome do seu pai deveria ser colocado à frente dos outros meses. Por outro lado, Numa Pompílio, homem pacífico e afamado pela paz e pelo ócio, terse-á esforçado por ter orientar os ânimos dos concidadãos da guerra para a agricultura, dando primazia a Janeiro entre outros meses, tendo por isso promovido o culto e grandes honras a Jano, como sendo mais amante da agricultura do que da guerra. Numa Pompílio assumira como início do ano o momento mais idóneo da natureza, na medida em que nos afecta. É mais sensato começar o ano depois do solestício de Inverno, quando o sol chega ao fim do seu progresso e de novo retoma novo ciclo. De facto, este início é natural para aumentarmos o tempo de luz e diminuirmos a noite escura.

53 Pedro Lain Entralgo, La Antropologia en la Obra deFray Luís de Granada, Consejo Superior de Investigaciones Científicas, Madrid, 1988. 
programa de Filosofia para uma uita beata e para a ratio perfecta - conceitos nodais no desenvolvimento do ethos do Homem e na conquista da fellicitas. Por isso, os conceitos axiológicos do Bom e da Verdade, aliados à felicitas, libertas, tranquillitas e sapientia aproxima-o do exemplum de Deus.

O Dominicano elucida, no entanto, sobre este caminho certo da virtude e recto da razão, na conquista da felicidade, veiculando uma mensagem de esperança ao mesmo tempo que derroga a expectativa de algum dia se atingir esse fim de sublimação. Mais importante do que o ponto culminante de qualquer trajecto é o caminho que se percorre até ele. É-nos revelado na Collectanea Moralis Philosophiae o lado mais defensável, a vertente mais ética, a face mais humanista e humana mas para sublinhar em contraponto a dificuldade de lá se chegar. $\mathrm{O}$ Homem nunca conseguirá ser perfeito pela simples razão de que a sua própria condição ontológica que o impede. Se Deus é uno e pleno nas suas dimensões, invulnerável ao Tempo pois tudo se inicia e se encerra nele mesmo, o Homem é em contraponto fragmentário e contingente, encerrado numa condição demiurgica $\mathrm{e}$ efémera, na qual imperam forças dissonantes e inconciliáveis. Deus, em toda a sua providência, graça e justiça intensifica esta dialéctica, sendo paradigma de fortuna e amor eterno que acentuam e agudizam a precaridade do Homem.

Tudo acompanha o veloz fluir do Tempo pela máxima de Heraclito: "não nos poderemos banhar duas vezes no mesmo rio, ainda que seu nome seja o mesmo, as águas são renovadas". O Tempo devora a Vida e presenteia-nos com a Morte: a Infância consome os primeiros anos, a Adolescência apodera-se da Infância e a Velhice toma conta da Juventude. Aprender a ser sábio é aceitar este fluir da vida, com a resignação de que não se perde o que nunca se teve. Não podemos prolongar a vida mas podemos melhorar a sua qualidade, da mesma forma que numa peça de teatro a duração se subordina à qualidade da representação.

O Homem é naturalmente incauto e insensato quando se deixa arrebatar, de forma despiciente, por uma dor desnecessária, uma alegria sem importância ou um desejo insaciável. Inadvertidamente, contamos como certo com o que detém a fortuna e subestimamos o que efectivamente está em nossas mãos, não há nenhuma outra forma de contornar a celeridade do tempo se não vivendo-o rapidamente. As prioridades são torpes e desajustadas: o Homem teme pela escassez de alimentos então esforça-se pela sua abundância; é movido pela angústia e ansiedade de uma alma titubeante e ao mesmo tempe mesmo sabendo da sua debilidade, alimenta sonhos e esperanças quiméricas.

A linhagem e a ontogénese dos homens é como a das folhas, umas caem para outras nascerem e este ciclo é naturalmente intravável, no qual o tempo que vivemos volta onde estava antes de termos nascido. Esta ciclicidade faz com que Vida e Morte 
sejam indissociáveis, pois para a existência de uma é necessária a outra e o Tempo não é mais do que um motor ou catalisador de ocorrências, que ceifa a ilusão de que tudo pode ser nosso para sempre. A nossa ilusão persiste na crença de que o Tempo é nosso de tal forma que o desperdiçamos tão negligentemente e durante grande parte da vida agimos mal, durante a maior parte não agimos nada e durante toda a vida agimos inutilmente.

A verdade e lucidez da mensagem granadina residem neste movimento incessante de consciência da aprendizagem, um itinerário que instiga o Homem a superar-se, ainda que com uma certa melancolia do que nunca terá/ será e com a nostalgia do que relega e abdica, inevitavelmente. O Homem assiste de forma irreversível a uma perda permanente e intravável do (seu) tempo, nesta agonia de memória e esquecimento. Consideremos, assim, a Collectanea um caleidoscópio da natureza humana, no qual se agudiza a realidade para melhor a representar. E se por um lado respondeu aos anseios de uma mundividência Renascentista, com a invocação de uma herança Clássica e perene, apela hoje a uma memória não menos actual e pertinente da condição humanista não fosse tão verdadeira a máxima virgiliana carpent tua poma nepotes (Virgílio, Bucólica IX, 50).
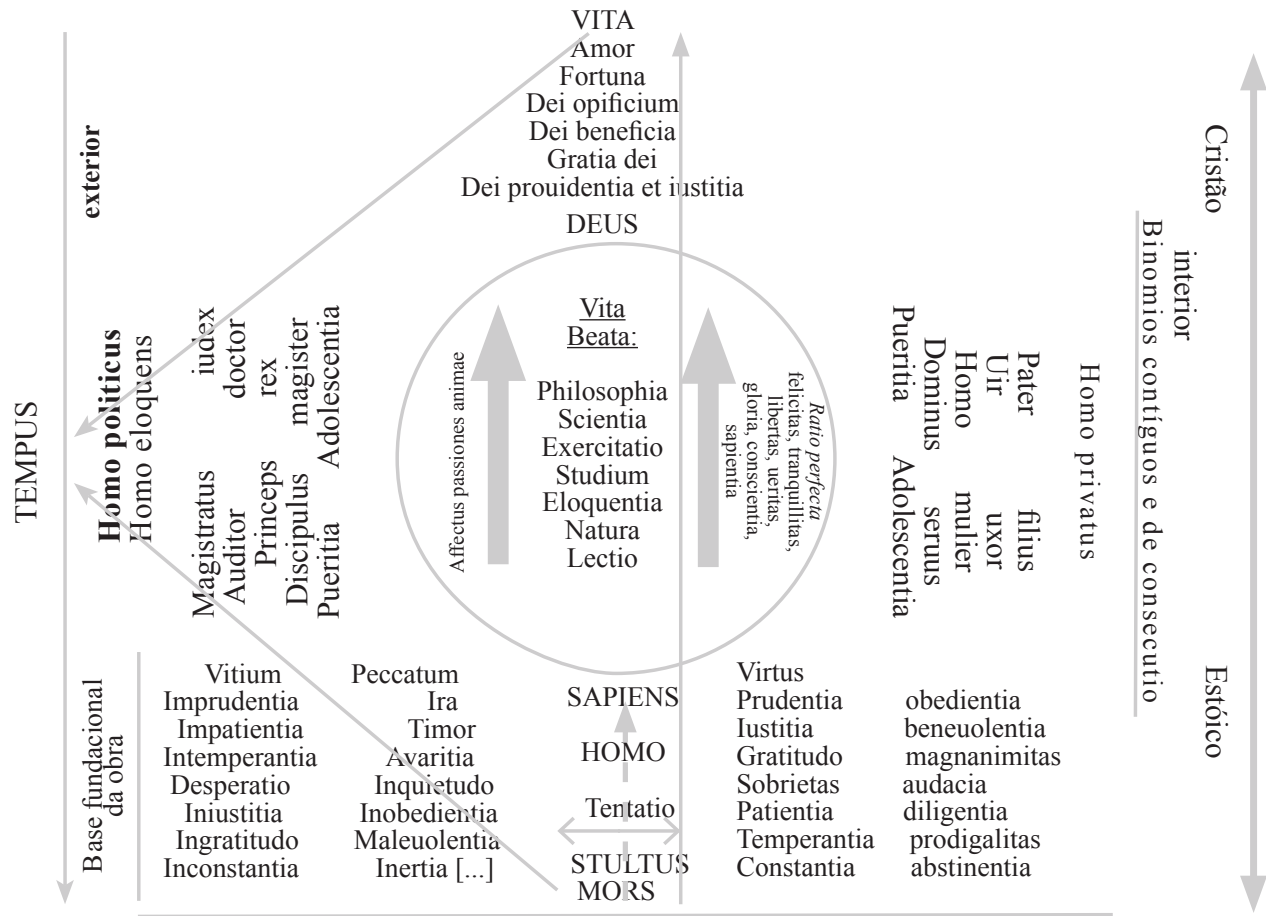

Binómios exiológicos:bona \& mala et vera \& falsa / Binómios dialécticos 


\section{Bibliografia}

Aldaz, José Aragues,

- "Colecciones de exempla y oratória: la labor del compilador" in Humanismo e Pervivencia del Mundo Clásico - Actas del I Simposio, Cádiz, 1993, pp. 251-267.

Aulotte, R.,

- Amyot et Plutarque - la tradition des Moralia au XVI, Droz, Genève, 1965.

- "Une rivalité d'humanistes. Érasme et Longueil, traducteurs de Plutarque", $B i$ bliothèque d'Humanisme et Renaissance, 30 (1968) 549-573.

Azorin,

- Los dos Luíses y otros ensayos, Coleccion Austral, Espasa Calpe, S.A, Buenos Aires, 1944.

BABUt, DANIEL,

- Plutarque de la Vertu Éthique, Société d'édition "Les Belles Lettres", Boulevard Raspail, Paris, 1969.

- Plutarque et le stoicisme, Presses Universitaires de France, Paris, 1969.

Buisson, François,

- Répertoire des ouvrages pédagogiques du XVI siècle, Nieuwoop, B. De Graaf, Paris, 1968.

Brentano, Mary Bernarda,

- Nature in the works of Fray Luís de Granada, Catholic University of America, Washington, 1969.

Cave, Terence,

- Cornucopia - Figures de l'abondance au XVI siècle : Erasme, Rabelais, Ronsard, Montaigne, Macula Collection Argo, Paris, 1997.

Compagnon, Antoine,

- La seconde main ou le travail de citation, Éditions du Seuil, Paris, 1979.

Cuervo, Fr. Justo de la Orden de Predicadores rector del Colegio de San Juan de Corias Doctor en Filosofia y Letras,
- Biografia de Fr. Luís de Granada com unos artículos literários donde se mustra que el venerable Padre y no San Pedro de Alcantara es el Verdadero y único autor del Libro de la Oración, Libreria de Gregorio del Amo, Madrid, 1895.

Entralgo, Pedro Lain,

- La Antropologia en la Obra de Fray Luís de Granada, Consejo Superior de Investigaciones Científicas, Madrid, 1988.

FAure, DominiQue,

- L'éducation selon Plutarque d'après les Oeuvres Morales, 2 vols, Aix-enProvence, 1960.

Ferreira, José Ribeiro,

- "Os valores de Plutarco e sua actualidade", in Ética e Paideia em Plutarco, Colecção Autores Gregos e Latinos, Série ensaios, $\mathrm{n}^{\circ} 1$, Coimbra, 2008.

Fuhrmann, François,

- Les images de Plutarque, Thèse pour le doctorat présentée à la Faculté des Lettres et Sciences Humaines de l'Université de Paris, Paris, 1964.

Fumaroli, Marc,

- L'âge de l'Éloquence Rhetorique et "res literaria" de la Renaissance au seuil de l'époque classique, Librairie Droz, Genève, 2002.

GonzÁlez VÁzQuez, José,

- "Valoración de la producción latina del renascimiento Granadino" in Clasicismo en el Renascimiento Granadino, Publicaciones de la Universidad de Granada, Granada, 1996, 317-341.

- "Humanismo y Clasicismo en la obra latina de Fray Luís de Granada", in I Congreso Nacional sobre Humanistas españoles, Léon, 1996.

Granada, Frei Luís,

- Collectanea moralis philosophiae: in tres tomos distributa; quorum primus selectissimas sententias ex omnibus Senecae operibus; secundus ex morali- 
bus opusculis Plutarchi; tertius clarissimorum \& philosophorum insigniora apophthegmata hoc est dicta memorabilia complectitur... / collectore F. Ludouico Granateñ. monacho dominicano, Olisippone : excudebat Franciscus Correa, 1571.

Hornero, Calixto P.,

- Elementos de Retórica com exemplos latinos de Cicerón y castelhanos de Frei Luís de Granada para uso de las Escuelas Pias, Madrid, 1815.

Kristeller, Paul Oskar,

- Renaissance concepts of man and other essays, Harper and Row, New York, 1971.

- Studies in Renaissance Thought and Letters, Edizioni Di Storia E Letteratura, Roma, 1969.

LÓPEZ MuÑoz, MANUEL,

- "Quintiliano, Agustin y Fray Luis de Granada ante la doctrina de la alegoria", Florentia Iliberritana, 3 (1992) 333-354.

MACK, PETER,

- The History of Renaissance Rhetoric 1380-1620, Oxford University Press Inc., New York, 2011.

Moreau, Pierre-François,

- Le Stoicisme au XVI et au XVII siècle, le retour des philosophies antiques à l'âge classique, Albin Michel, Paris, 1999.

Newman, SARA,

- "Aristotle's Notion of " bringing-beforethe-eyes" its contributions to Aristotelian and contemporary conceptualizations of Metaphor, Style and Audience", RHETORICA - A Journal of the History of Rhetorica, 20 (2002) 1-23.

Plett Heinrich,

- Intertextuality, Walter de Gruyter, Berlin, 1991.

Rodrigues, Maria IdAlina Resina,

- Fray Luis de Granada y la literatura de espiritualidade en Portugal, Fundación Universitária Española, Madrid, 1988.

Soares, Nair de Nazaré Castro et alii,

- Homo eloquens et homo politicus. A Retórica e a construção da cidade da Idade Média e no Renascimento, Centro de Estudos Clássicos e Humanísticos, Coimbra, 2009.

- O Príncipe Ideal no Século XVI e a Obra de D. Jerónimo Osório, Instituto Nacional de Investigação Científica, Coimbra, 1994.

- "A Historiografia do Renascimento em Portugal: Referentes estéticos e ideológicos Humanistas" in Aquém e Além da Taprobana, Estudos LusoOrientais à memória de Jean Aubin e Denys Lombard, Centro de História e de Além-Mar, Lisboa, 2002.

- "A literatura de sentenças no Humanismo Português: res et uerba, Humanitas 43-44 (1991-1992) 377-410 (= Actas do Congresso Internacional Humanismo Português na época dos Descobrimentos, Coimbra, 1993).

- "Humanismo e História: ars scribendi e valor do paradigma", Universidade Católica Portuguesa", Sep. De Máthesis 1, Coimbra, 1992.

Thorsteinsson, Runar M.

- Roman Christianity \& Roman Stoicism: A comparative Study of Ancient Morality, Oxford University Press, Oxford, 2011.

Turrado, Agustin, O.P. Director del Colegio Mayor "Santa Cruz la Real",

- "Granada nel estilo literário de Fray Luis" in Fray Luis de Granada, IV Centenário 1588/1988, Organizan Dominicos de Andalucia, Universidad de Granada.

ZANTA, LÉONTINE,

- La Renaissance du stoicisme du XVI siècle, Librairie Édouard Champion, $\mathrm{Pa}$ ris, 1914. 
Anexos 


\begin{tabular}{|c|c|c|c|c|c|c|c|c|c|c|c|c|c|c|c|c|c|}
\hline & $\begin{array}{l}\text { De util. cap. } \\
\text { ab inim. }\end{array}$ & & & & & & & & & & & & & & & + & \\
\hline & $\begin{array}{l}\text { De vit. } \\
\text { verecundia }\end{array}$ & & & & & & & & & & & & & + & + & & \\
\hline & $\begin{array}{l}\text { De docenda } \\
\text { uirt. }\end{array}$ & & & & & & & & & & & & + & & & & \\
\hline & $\begin{array}{l}\text { De tranq. } \\
\text { animi }\end{array}$ & & & & & & & & & & & & + & & & & \\
\hline & $\begin{array}{l}\text { De prof. } \\
\text { moris }\end{array}$ & & & & & & & & & & + & & & & & & \\
\hline & $\begin{array}{l}\text { De officio } \\
\text { auditoris }\end{array}$ & & & & & & & & & + & & & & & & & \\
\hline & $\begin{array}{l}\text { De disput. phi- } \\
\text { losophorum }\end{array}$ & & & & & & & & & + & & & + & & & & \\
\hline & In Politica & & & & & & & & & + & & & + & + & + & + & \\
\hline & $\begin{array}{l}\text { De doct. } \\
\text { Uirt. }\end{array}$ & & & & & & & & + & & & & & & & & \\
\hline & $\begin{array}{l}\text { De officio } \\
\text { auditoris }\end{array}$ & & & & & & & & + & + & & & & & & & \\
\hline & In probl. & & & & & & & + & & & & + & & + & & & \\
\hline & $\begin{array}{l}\text { De tuenda bo- } \\
\text { na ualetudine }\end{array}$ & & & & & + & & & & & & & & & & & \\
\hline & $\begin{array}{l}\text { De uirt. } \\
\text { morum }\end{array}$ & & & & & + & & & & & & & & & & & \\
\hline & De fort. & & & & + & & & & & & & & + & & & & \\
\hline$\stackrel{\circlearrowright}{\Xi}$ & De lib. educ. & & & + & & & + & & + & & & & & & & & \\
\hline$\frac{0}{0}$ & $\begin{array}{l}\text { De sera } \\
\text { Num. Uind. }\end{array}$ & & + & & + & & & & & & & & & & & & \\
\hline ల్ & $\begin{array}{l}\text { De doct. } \\
\text { princ. }\end{array}$ & + & & & & & & & & & & & + & & & & + \\
\hline ల్ల & De exilio & + & & & & & & & & & & & & & & & \\
\hline $\begin{array}{l}\sum_{1}^{\infty} \\
\stackrel{\ominus}{\ominus} \\
\sum_{0}\end{array}$ & 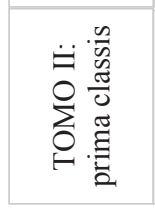 & $\stackrel{\tilde{D}}{0}$ & 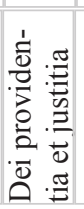 & 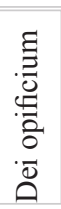 & 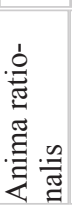 & 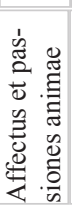 & 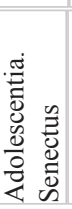 & 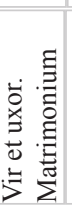 & 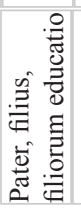 & 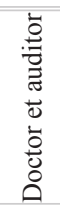 & 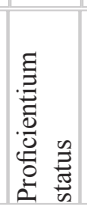 & 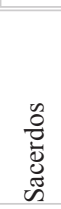 & 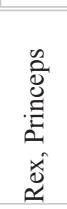 & 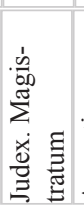 & 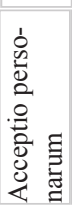 & 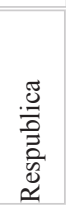 & 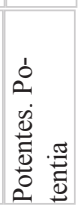 \\
\hline
\end{tabular}




\begin{tabular}{|c|c|c|c|c|c|c|c|c|c|c|c|c|c|c|c|c|c|c|c|c|c|c|c|c|c|c|c|c|c|c|c|c|c|c|c|}
\hline $\begin{array}{l}\text { TOMO II: } \\
\text { sec. classis }\end{array}$ & -r. & $=:$ & $\Xi \vdots$ & 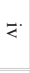 & $<$ & $\leq$ & $\leqq$ & $\leqq:$ & $\bar{x}$ & * & $\underline{.}$ & 肴: & 产: & …라. & æ̌ & $\stackrel{x}{s}$ & : & : & : & $\ddot{x}$ & 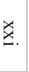 & 峞: & 忘: & 屁. & 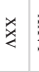 & s. & $\stackrel{\text { L }}{\vdots}$ & : & : & 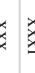 & 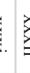 & : & 次 & 玄 & . \\
\hline Virtus & & & & + & & & & & & & & & & & & & & & + & & & & & & & & & & & & & & & & \\
\hline $\begin{array}{c}\text { Vera et falsa } \\
\text { uirtus }\end{array}$ & & & & & & & & & & & & & & & & & & & & + & + & & & & & & & & & & & & & & \\
\hline Virtus in medio & & & & + & & & & & & & & & & & & & & & & & & & & & & & & & & & & & & & \\
\hline $\begin{array}{c}\text { Virtus quomodo } \\
\text { facilis }\end{array}$ & & & & & & & & & & & & & + & & & & & & & & & & & & & & & & & & & & & & \\
\hline Tentatio & & & & & & & & & & & & & & + & & & & & & & & & & & & & & & & & & & & & \\
\hline $\begin{array}{l}\text { Conscientia } \\
\text { bona et mala }\end{array}$ & & & + & & & & & & & & & & & & + & & & & & & & & & & & & & & & & & & & & \\
\hline $\begin{array}{l}\text { Societas } \\
\text { bonorum }\end{array}$ & & & & & & & & & & & & + & & & & & & & & & & + & & & & & & & & & & & & & \\
\hline Amor sui & & & & & & & & & + & & & & & & & & & & & + & & & & & & & & & & & & & & & \\
\hline $\begin{array}{l}\text { Dilectio erga } \\
\text { inimicos }\end{array}$ & & & & & & & & + & & & + & & & & & & & + & & & + & & & & & & & & & & & & & & \\
\hline $\begin{array}{c}\text { Amicitia vera } \\
\text { et falsa }\end{array}$ & & & & & & & & & & & & & & & & & & & & & & & & & & & & & & & & & & & \\
\hline Pax. Concordia & & & & & & & & & & & + & & & & & & & & & & & & & & & & & & & & & & & & \\
\hline Bellum & & & & + & & & & & & & & & & & & & & & & & & & & & & & & & & & & & & & \\
\hline Seditio. Factio & & & & & & & & & & & + & & & & & & & & & + & & & & & & & & & & & & & & & \\
\hline $\begin{array}{l}\text { Consolatio } \\
\text { aflictorum }\end{array}$ & & & & & & & & & & & & & & & & & & & & & & & & + & & & & & & & & & & & \\
\hline $\begin{array}{l}\text { Admonitio. } \\
\text { Castigatio }\end{array}$ & & & & + & & & & & & & + & & & & & & & & & + & & & & & & & & & & & & & & & \\
\hline Invidia & & & & & & & & & & & + & & & & + & & & & & & & & & & + & & & & & & & & & & \\
\hline $\begin{array}{c}\text { Inertia, contra- } \\
\text { que diligentia }\end{array}$ & & & & + & & & & & & & & & & & & & & & & & & & & & & & & & & & & & & & \\
\hline $\begin{array}{c}\text { Benevolentia } \\
\text { civium captanda } \\
\text { et malevolentia } \\
\text { fugienda }\end{array}$ & & & & & & & & & & & + & & & & & & & & & & & & & & & & & & & & & & & & \\
\hline Prudentia & & & & & & + & & & & & & & & & & & & & & & & & & & & & & & & & & & & & \\
\hline Justitia & & + & & & & & & & & & & & & & & & & & & & & & & & & & & & & & & & & & \\
\hline Usura & & & & & & & & & & & & & & & & & & & & & & & & & & & + & & & & & & & & \\
\hline
\end{tabular}




\begin{tabular}{|c|c|c|c|c|c|c|c|c|c|c|c|c|c|c|c|c|c|c|c|c|c|c|c|c|c|c|c|c|c|}
\hline $\begin{array}{l}\text { TOMO II: } \\
\text { sec. classis }\end{array}$ & -. & $=:$ & $\Xi:=$ & $=<$ & $\leq$ & $\leqq: \leqq:$ & $\ddot{x}$ & $x$ & $\succeq$. & $\underline{\underline{u}}:$ & 害: & $\frac{x}{x}$ & $\stackrel{x}{s}$. & $\stackrel{\stackrel{x}{y}}{=}$ & $\stackrel{x}{\stackrel{x}{x}}$ & $\ddot{x}$ & 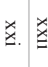 & 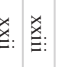 & $\stackrel{x}{x}$ & . & : & 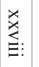 & 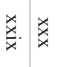 & 苔. & 㒸: & : & . & & . \\
\hline Restitutio & & & & & & & & & + & & & & & & & & & & & & & & & & & & & & \\
\hline $\begin{array}{l}\text { Contumelia. } \\
\text { Convivium }\end{array}$ & & & & & & & & & & & & & & & + & & & & & & & + & & & & & & & \\
\hline $\begin{array}{l}\text { Adulatio contra- } \\
\text { que libertas } \\
\text { admonenda }\end{array}$ & & & + & & & & & & & & & & & & & + & & & & & & & & & & & & & \\
\hline Religio & & & & & & + & & & & & & & & & & & & & & & & & & & & & & & \\
\hline $\begin{array}{l}\text { Sacrificium. } \\
\text { Oblatio }\end{array}$ & & & & & & + & & & & & & & & & & & & & & & & & & & & & & & \\
\hline $\begin{array}{l}\text { Pietas in } \\
\text { patriam }\end{array}$ & & & & & & & & & + & & & & & & & & & & & & & & & & & & & & \\
\hline $\begin{array}{c}\text { Observantia in } \\
\text { majores }\end{array}$ & & & & & & & & & + & & & & & & & & & & & & & & & & & & & & \\
\hline $\begin{array}{l}\text { Gratitudo in } \\
\text { Deum }\end{array}$ & & & & & & & & & + & & & & & & & & & & & & & & & & & & & & \\
\hline Contemplatio & & & & & & & & & & & + & + & & & & & & & & & & & & & & & & & \\
\hline Juramentum & & & & & & + & & & & & & & & & & & & & & & & & & & & & & & \\
\hline Mendacium & & & & & & & & & & & & & & & & & & & & & + & & & & & & & & \\
\hline Obedientia & & & & & & & & & + & & & & & & & & & & & & & & & & & & & & \\
\hline Liberalitas & & & & & & & & & & + & & & & & & & & & & & & & & & & & & & \\
\hline $\begin{array}{c}\text { Avaritia. } \\
\text { Prodigalitas }\end{array}$ & & & & & & & & & & & & & & & & & & & & & & & & & & & & & + \\
\hline $\begin{array}{c}\text { Divitiae. } \\
\text { Divites }\end{array}$ & & & & & & & & & & & & & & & & & & & & & & + & & & & & & & + \\
\hline Paupertas & + & & & & & & & & & & & & & & & & & & & & + & & & & & & & & \\
\hline Fortitudo & & & & + & & & & & & & & & & & & & & & & & & + & & & & & & & \\
\hline $\begin{array}{c}\text { Fortunae } \\
\text { inconstantia }\end{array}$ & & & & + & & & & & & & & & & & & & & & & & & & & & & & & & \\
\hline $\begin{array}{l}\text { Fortunae utrius- } \\
\text { que contemptus } \\
\text { et moderatio }\end{array}$ & & & & & & & & & & & & + & & & & & & & & & & & & & & & & & \\
\hline Prosperitas & & & & & & & & & + & & & & & & & & & & & & & & & & & & & & \\
\hline
\end{tabular}




\begin{tabular}{|c|c|c|c|c|c|c|c|c|c|c|c|c|c|c|c|c|c|c|c|c|c|c|c|c|c|c|c|c|c|}
\hline $\begin{array}{l}\text { TOMO II: } \\
\text { sec. classis }\end{array}$ & -. & $=: \quad \Xi$ & $=$ & $<$ & $\leq$. & $\leqq:$ & $\leqq:$ & $\bar{x} \times$ & $\times \quad \check{.}$. & ㅆ. & 网: & ç & $\stackrel{x}{a}$ & 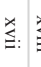 & : & $\ddot{x}$ & 范. & : & 庇 & 產 & 肴. & 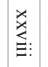 & 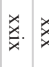 & 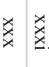 & : & 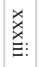 & & $x$ & 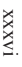 \\
\hline Adversitas & & & & & & & & & & & & & & - & + & & & & & & & & & & & & & & \\
\hline $\begin{array}{c}\text { Persecutiones } \\
\text { contra viros } \\
\text { bonos }\end{array}$ & & & & & & & & + & & & & & & & & & & & & & & & & & & & & & \\
\hline $\begin{array}{l}\text { Patientia. } \\
\text { Impatientia }\end{array}$ & + & & & & & & & & & & & & & & & & & & + & & & & & & & & & & \\
\hline Constantia & + & & & & & & & & & & & + & & & & & & & & & & & & & & & & & \\
\hline $\begin{array}{l}\text { Temperantia. } \\
\text { Intemperantia }\end{array}$ & & & & & + & & & & & & & & & & & & & & & & & & & & & & & & \\
\hline Luxus & & & & & & & & & & & & & & & & & & & & & & & & & & & & & + \\
\hline Abstinentia & & & & & & + & & & & & & & & & & & & & & & & & & & & & & & \\
\hline Gula & & & & & & & + & & & & & & & & & & & & & & & + & & & & & & & \\
\hline Ebrietas & & & & & & & & & & & & & & & & & + & & & & & & & & & & & & \\
\hline $\begin{array}{l}\text { Castitas. } \\
\text { Celibatus }\end{array}$ & & & & + & & & + & & & & & & & & & & & & & & & & $\begin{array}{lll}+ & & \end{array}$ & & & & & & \\
\hline $\begin{array}{l}\text { Clementia. } \\
\text { Mansuetudo }\end{array}$ & & & & & & & & & + & & & & & & & & + & & & & & & & & & & & & \\
\hline $\begin{array}{l}\text { Mansuetudo. } \\
\text { Ira }\end{array}$ & & & & & & & & & & & & & & & & & + & & & & & & & + & & & & & \\
\hline $\begin{array}{c}\text { Recreatio sive } \\
\text { relaxatio animi }\end{array}$ & & & + & & & & & & & & & & & & & & & + & & & & & & & & & & & \\
\hline Cognitio sui & & & & & & & & & & & & & & & & & & & & & & & & + & + & & & & \\
\hline $\begin{array}{l}\text { Abnegatio sui } \\
\text { vel affectum } \\
\text { cohibitio, sive } \\
\text { contientia }\end{array}$ & & & & & + & & & & & & & + & & + & & & & & & & & & & & + & & & & \\
\hline $\begin{array}{c}\text { Quies sive } \\
\text { tranquillitas } \\
\text { animi }\end{array}$ & + & & & & & & & & & & & + & & & & & & & & & & & & & & + & & & \\
\hline $\begin{array}{l}\text { Inquietudo } \\
\text { animi, Curae. } \\
\text { Distractio }\end{array}$ & & & & & & & & & & & & + & & & & & & & & & & & & & & & & & \\
\hline Modestia & & & & & & & & & + & & & & & & & & & & & & & & & & & & & & \\
\hline $\begin{array}{l}\text { Linguae } \\
\text { moderatio }\end{array}$ & & & + & & & & & + & & & & & & & & & & & & & & & & & & & & & \\
\hline Drnatus vestium & & & & & & & + & & & & & & & & & & & & & & & & & & & & & & \\
\hline
\end{tabular}




\begin{tabular}{|c|c|c|c|c|c|c|c|c|c|c|c|c|c|c|c|c|c|c|c|c|c|c|c|c|c|c|c|c|c|}
\hline $\begin{array}{l}\text { TOMO II: } \\
\text { sec. classis }\end{array}$ & - . & $=:$ & $\Xi \vdots:$ & $<<\frac{1}{2}$ & $<\leq$. & $\leqq:$ & & $\vec{x} \cdot \times$ & $\simeq$ & $\stackrel{\mathrm{x}}{=}:$ & 息: & $\stackrel{x}{z}$ & 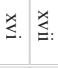 & : & 率: & & 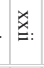 & 㕍: & x & $\frac{x}{x}$ & : & 肴: & : & 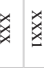 & : & : & 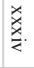 & 厐 & \\
\hline $\begin{array}{l}\text { Verecundia. } \\
\text { Pudor }\end{array}$ & & & & & & & & & & & & & + & & & & & & & & + & & & & & & & & \\
\hline Philosophia & & & + & + & & & & & & & & & & & & & & & & & + & & & & & & & & \\
\hline Poetice & & & & & & & & & & & & & & & & & & & & & & & & & & & & & \\
\hline $\begin{array}{l}\text { Curiositas } \\
\text { improbanda }\end{array}$ & & & & & & & & & & & & & & & & & & & & & & & & & + & & & & \\
\hline $\begin{array}{l}\text { Ambitio, con- } \\
\text { traque honoris } \\
\text { contemptos }\end{array}$ & & & & & & & & & + & & + & & & & & & & & & & & & & & & & & & \\
\hline Honor & & & + & + & & & & & & & & & & & & & & & & & & & & & & & & & \\
\hline Hypocrisis & & & & & & & & & & & & & & & & & + & & & & & & & & & & & & \\
\hline Eloquentia & & & + & + & & & & & & + & & & & & & & & & & & + & & & & & & & & \\
\hline $\begin{array}{c}\text { Studium scien- } \\
\text { tiae, discendi } \\
\text { ardor }\end{array}$ & & & & & & & & + & & & & & & & & & & & & & + & & & & & & & & \\
\hline Veritas & & & & & & & + & & & & & & & & & & & & & & & & & & & & & & \\
\hline Consuetudo & & & & & & & & & & & & & & & & & & & & & & & & & & & + & & \\
\hline Tempus & & & & & & & + & & & & & & & & & & & & & & & & & & & & & & \\
\hline Vita & & & & & & & & & & & & & & & & & & + & + & & & & & & & & & & \\
\hline Mors & & & & & & & & & & & & & & & & & & $t$ & + & & & & & & & & & & \\
\hline Inferorum regio & & & & & & & & & & & & & & & & & & + & + & & & & & & & & & & \\
\hline $\begin{array}{l}\text { Beatorum men- } \\
\text { tium regio }\end{array}$ & & & & & & & & & & & & & & & & & & + & $\begin{array}{l}+ \\
+\end{array}$ & & & & & & & & & & \\
\hline $\begin{array}{l}\text { Felicitas vera } \\
\text { et falsa }\end{array}$ & & & & & & & & & & & & & & & & & & & & & & & & & & & + & & + \\
\hline $\begin{array}{c}\text { Mixtus ex di- } \\
\text { versis sententiis } \\
\text { locus }\end{array}$ & & & + & & & & & & & & & & & & & & & & & & & & & & & & & & \\
\hline
\end{tabular}


Legenda do II tomo, secunda classis

i) De exilio

ii) De doctrina principum

iii) De Num. Uindicta

iv) De liberis educandis

v) De fortuna et uirtute Alexandri

vi) De virtute morum

vii) De tuenda bona ualetudine

viii) In Problematibus

ix) De officio auditoris

x) De doctrina uirtutis

xi) In Politica

xii) De disput. philosophorum

xiii) De officio auditoris

xiv) De profectu morum

xv) De tranq. animi

xvi) De docenda uirtute

xvii) De vitiosa verecundia

xviii) De utilitate capienda ab inimicis

xix) De utilitate cap.ex inimico xx) De discrimine adulatoris et amici

xxi) De cohibenda iracundia

xxii) Num philosophandum inter pocula

xxiii) De amicitia in multos diffusa

xxiv) In oratione consolatoria

xxv) De odio et inuidia

xxvi) De bene lateat uiuens

xxvii) De vitanda usura

xxviii) De audiendis poetis

xxix) De claris mulieribus

xxx) De nota Pythagorae

xxxi) Utrum grauiores sint animi morbi quam corporis

xxxii) De curiositate

xxxiii) Cum principibus philosophandi

xxxiv) De virtute et uitio

xxxv) Bene lateat uiuens

xxxvi) De cupiditate divitiarum

xxxvii) De amicitia in multos diffus 